This is an electronic reprint of the original article. This reprint may differ from the original in pagination and typographic detail.

Author(s): Sääskilahti, Jaakko

Title: Local bank competition and small business lending after the onset of the financial crisis

Year: $\quad 2016$

Version:

Please cite the original version:

Sääskilahti, J. (2016). Local bank competition and small business lending after the onset of the financial crisis. Journal of Banking and Finance, 69(August), 37-51. https://doi.org/10.1016/j.jbankfin.2016.04.004

All material supplied via JYX is protected by copyright and other intellectual property rights, and duplication or sale of all or part of any of the repository collections is not permitted, except that material may be duplicated by you for your research use or educational purposes in electronic or print form. You must obtain permission for any other use. Electronic or print copies may not be offered, whether for sale or otherwise to anyone who is not an authorised user. 


\section{Accepted Manuscript}

Local bank competition and small business lending after the onset of the financial crisis

\section{Jaakko Sääskilahti}

PII:

$$
\text { S0378-4266(16)30028-0 }
$$

DOI: http://dx.doi.org/10.1016/j.jbankfin.2016.04.004

Reference: JBF 4933

To appear in:

$$
\text { Journal of Banking \& Finance }
$$

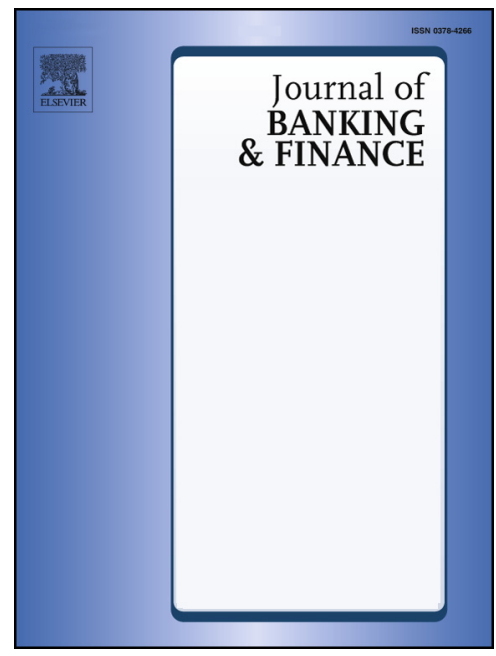

Received Date: $\quad 7$ October 2014

Accepted Date: $\quad 8$ April 2016

Please cite this article as: Sääskilahti, J., Local bank competition and small business lending after the onset of the financial crisis, Journal of Banking \& Finance (2016), doi: http://dx.doi.org/10.1016/j.jbankfin.2016.04.004

This is a PDF file of an unedited manuscript that has been accepted for publication. As a service to our customers we are providing this early version of the manuscript. The manuscript will undergo copyediting, typesetting, and review of the resulting proof before it is published in its final form. Please note that during the production process errors may be discovered which could affect the content, and all legal disclaimers that apply to the journal pertain. 


\title{
Local bank competition and small business lending after the onset of the financial crisis
}

Jaakko Sääskilahti

Address: University of Jyvaskyla, School of Business and Economics, P.O. BOX 35, FI-40014

University of Jyvaskyla, Finland

E-Mail address: jaakko.s.saaskilahti@student.jyu.fi

Tel.: +358504307585

This version: 15.3.2016

\begin{abstract}
This paper examines whether the effects of the financial crisis on the volumes and prices of small business loans depended on the pre-crisis local competitive environment. To address this question, I employ a unique data set on Finnish cooperative banks. I find that the monthly volumes of new business loans decreased and the average loan margins increased after the onset of the crisis. The decrease in volumes and the increase in margins were greater in local banking markets that were more competitive before the crisis. The results for the loan margins are more robust than those obtained for the volumes. Auxiliary analyses suggest that the greater effects in the more competitive markets are due to competition leveling therein more after the onset of the crisis.
\end{abstract}

Keywords: financial crisis, small business lending, local bank competition JEL classification: G01, G21, L11 


\title{
Local bank competition and small business lending after the onset of the financial crisis
}

\author{
Abstract \\ This paper examines whether the effects of the financial crisis on the volumes and prices of small \\ business loans depended on the pre-crisis local competitive environment. To address this question, I \\ employ a unique data set on Finnish cooperative banks. I find that the monthly volumes of new \\ business loans decreased and the average loan margins increased after the onset of the crisis. The \\ decrease in volumes and the increase in margins were greater in local banking markets that were \\ more competitive before the crisis. The results for the loan margins are more robust than those \\ obtained for the volumes. Auxiliary analyses suggest that the greater effects in the more competitive \\ markets are due to competition leveling therein more after the onset of the crisis. \\ Keywords: financial crisis, small business lending, local bank competition \\ JEL classification: G01, G21, L11
}




\section{Introduction}

The availability and cost of bank loans are crucial for many small businesses because these businesses often lack other options for external funding (Berger and Udell, 1998; Carbo-Valverde et al., 2009). Small business lending has traditionally been local because small firms are often informationally opaque (e.g., Agarwal and Hauswald, 2010). Thus, the availability and cost of loans to small businesses can depend on the behavior of competing local banks. When uncertainty is high, especially during crises, loan availability often declines to the greatest extent for opaque small businesses (see e.g., ECB, 2014).

In this paper, I examine whether, and if so how, the effect of the recent financial crisis on small business lending depended on the pre-crisis local competitive environment. In the previous literature, changes in loan supply during crises have been explained by bank balance sheet factors (e.g., Bernanke and Lown, 1991; Jiménez et al., 2012a). Studies concerning the availability and costs of bank loans during the recent crisis have, in particular, focused on the role of the bank funding structure (Cornett et al., 2011; Ivashina and Scharfstein, 2010) and examined the effects of loan losses (Puri et al., 2011; Santos, 2011) and more indirect factors, such as changes in risk tolerance (Albertazzi and Marchetti, 2010). I contribute to this literature by examining whether differences in banks' pre-crisis competitive environments explain why the changes in the volumes and prices of small business loans were heterogeneous after the onset of the financial crisis.

There is a wide body of literature on the relationship between market structure or bank competition and loan availability and prices (e.g., Carbo-Valverde et al., 2009; Chong et al., 2013; Hannan, 1997; Rice and Strahan, 2010). I consider the implications of this relationship for changes in lending behavior after the onset of the crisis. Differences in the pre-crisis competitive environments can explain heterogeneous changes in loan volumes and prices following a crisis, because there is a greater (lesser) scope for competition to decrease (increase) in markets where it was fierce (lax) to begin with. According to Ruckes (2004), the degree of competition generally 
decreases during crises, but changes in the degree of competition is not the only potential moderating factor. In addition, characteristics relevant for lending during crises — such as risk position, relationship banking and funding structure — can depend on the competitive environment (e.g., Boyd and De Nicolo, 2005; Craig and Dinger, 2013; Keeley, 1990; Petersen and Rajan, 1995). I therefore also consider various explanations for the relationship between the pre-crisis competitive environment and changes in lending after the onset of the crisis. I do so by examining how the change in the degree of competition after the onset of the crisis and the above mentioned bank characteristics depends the pre-crisis competitive environment.

I employ unique data on local cooperative banks of the Finnish OP-Pohjola Group. These data include monthly data on new small business loan volumes and average margins from 2004 to 2010. I also utilize data on local economic characteristics and on the number of bank branches for each local banking market. My empirical identification makes use of the fact that the cooperative banks operate in differently competitive local markets, but they are similar in numerous respects as they share a common business model and group culture. The group culture and structure ensures that the lending information and the data used to control for bank-specific factors are consistent across the banks. In addition, my empirical identification relies on the collapse of Lehman Brothers and the subsequent turbulence in money markets. These events exaggerated both uncertainty and the poor economic outlook but were completely exogenous to the Finnish banking sector and economy. ${ }^{1}$ Local demand conditions, particularly their adaption after the onset of the crisis, are controlled using local economic variables and separate province-specific time trends for the pre-crisis and crisis periods.

\footnotetext{
${ }^{1}$ For example, according to Laeven and Valencia (2013), no systemic banking crisis occurred in Finland from 2008 to 2010, and the effects of the global financial crisis on banking are primarily attributable to external factors.
} 
Because accurate measurement of bank competition is very challenging, I measure the competitiveness of local banking markets in two ways. My first measure is the standard HerfindahlHirschmann index (HHI). This index mirrors the market structure and is based on the number of branches of various banks in the main operating area of each cooperative bank. The second measure is the Lerner index, which refers to the gap between prices and marginal costs. It is a more direct measure of competition and has been used widely in the previous banking literature (Carbo et al., 2009).

My results indicate that the pre-crisis competitiveness of local banking markets affects how lending changed in response to the crisis. First, I find that after the onset of the financial crisis, the volumes of new small business loans decreased to a greater extent among the banks that operated in more competitive local markets before the crisis. In line with the previous literature, the volumes also decreased to a greater extent among the banks that were the most dependent on market-based funding (see e.g., Cornett et al., 2011; Gozzi and Goetz, 2010; Ivashina and Scharfstein, 2010; Iyer et al., 2014) ${ }^{2}$. Second, I find that the margins of new business loans increased to a greater extent among the banks that operated in more competitive local markets before the crisis. The loan margins were lower in the more competitive local markets to start with, in line with previous studies (e.g., Hannan, 1997). However, the difference between the more and less competitive markets diminished significantly after the onset of the crisis. This result indicates that differences in the precrisis competitive environments explain the heterogeneous effects of the crisis on loan prices.

My auxiliary analysis suggests that heterogeneous changes in the degree of competition is the main reason why banks' responses to the crisis vary across local markets with the different precrisis competitive environments. I find that after the onset of the crisis, the values of the competition measures and prices of various deposits and loans converged in the more competitive banking markets toward those of the less competitive banking markets. My results based on loan-specific

\footnotetext{
${ }^{2}$ Accordingly, the relative share of retail deposit funding is lower in these banks than in other banks.
} 
data allow me to largely rule out the claim that changes in small business credit risks or bank risktaking would explain the greater increases in loan margins in local markets that were more competitive before the crisis. Instead, the relatively lesser deterioration of average credit ratings of small business customers among the banks that operated in more competitive markets before the crisis tentatively supports the "flight to quality" explanation for greater volume declines. ${ }^{3}$ I find also that the banks that faced fiercer competition before the crisis were more dependent on market-based funding at the onset of the crisis. ${ }^{4}$ This association between the degree of competition and the dependence on market-based funding suggests an indirect effect of the pre-crisis competitive environment on lending behavior after the onset of the crisis.

Overall, my results indicate that differences in local competitive environments can induce heterogeneous changes in lending conditions between normal and crisis periods. This finding is relevant for bank regulation and supervision because it has implications for the debate over why there is excessive pro-cyclicality in lending. The results also complement Adams and Amel (2011), who study how the local market structure affects the pass-through of the federal funds rate.

Moreover, these results suggest that the heterogeneous effects of crises on local economies transmitted through local banks (see Gozzi and Goetz, 2010) can also depend on the prevailing local competitive environments.

The remainder of this paper proceeds as follows: In the next section, I review previous theoretical and empirical literature to lay the foundations for my paper. Section 3 describes the data and empirical approach. The main results are presented in section 4. I discuss the results in section 5, where I also report a series of auxiliary analyses. Section 6 concludes.

\footnotetext{
${ }^{3}$ The flight to quality phenomenon means that banks decrease lending relatively more to customers with high agency costs during crises (Bernanke et al., 1996).

${ }^{4}$ Accordingly, the relative share of retail deposit funding is lower in these banks than in other banks.
} 


\section{Competitive environment and lending in normal and crisis periods}

In this section, I consider how the competitive environment can affect loan availability and prices as well as certain bank characteristics. Based on this, I argue how different pre-crisis competitive environments can induce heterogeneous changes in lending after the onset of a crisis.

\section{Loan pricing and lending standards}

The market power hypothesis suggests that competition reduces loan prices and improves availability (e.g., Carbo-Valverde et al., 2009). Numerous empirical papers support this hypothesis. Hannan (1997) examines US small business loans at the Metropolitan Statistical Area (MSA) level and finds that banks charge lower loan rates in more competitive markets. Corvoisier and Gropp (2002) use country-level European data and report a positive relationship between concentration and loan prices. Degryse and Ongena (2005) find that a firm's distance from rival banks of the lending bank is positively related to the loan rates it pays. Petersen and Rajan (1995) find, somewhat contrary to the hypothesis, that a higher concentration decreases loan rates for young and small firms in the U.S., but the effect diminishes as firms age. Ruckes (2004) theoretically describes how price competition intensifies during boom periods and diminishes during bust periods, but to my knowledge, no empirical analyses examine how changes in loan prices between boom and bust periods are related to changes in competition.

Lending standards, i.e., the strictness of various loan terms, is one way to explore changes in loan availability. The ECB Bank Lending survey asks banks to describe their lending standards, and it divides the relevant factors affecting these standards into three groups: competition, balance sheet position and risk perception (Berg et al., 2005). The lending standards in this survey include prices, collateral requirements, maturity, size, covenants and the loan-to-value ratio of loans. Empirical studies find that changes in lending standards based on surveys explain changes in credit growth and loan availability (Demiroglu et al., 2012; Lown and Morgan, 2006). 
The relationship between competition and lending standards other than price has received little consideration. The theories of Ruckes (2004) and Dell'Ariccia and Marquez (2006) provide explanations for the relationship between increased competition and loosened lending standards. Dell' Ariccia and Marquez (2006) argue that the threat of competition or a larger number of competing banks can prompt reduced lending standards to protect or increase market shares. Ruckes (2004) argues that the increased average quality of customers in good times decreases the incentives of screening, which leads to increased competition and loosened lending standards and vice versa in bad times. Empirical work supports the view that lending standards are countercyclical and that they play a role in procyclical lending behavior, but such work does not examine the role of competition in this context (Asea and Blomberg, 1998; Dell'Ariccia et al., 2012; Peydró and Maddaloni, 2011). Jiménez and Saurina (2006) describe increasing competition as one of the possible reasons for looser lending standards during boom periods, but they do not examine its effect in detail. According to the ECB bank lending surveys, competition from other banks normally eases lending standards. However, this easing effect of competition on lending standards was not observed between the third quarter of 2007 and the third quarter of 2009, which suggests diminished competition during this period. ${ }^{5}$

Risks and risk-taking

The traditional yiew is that fiercer bank competition increases risks. According to this competition-fragility view, greater competition leads to lower profit margins and franchise value, which encourages greater risk-taking (Keeley, 1990). In contrast, the competition-stability view suggests that higher prices in less competitive markets may cause greater repayment problems and exacerbate moral hazard and adverse selection problems (Boyd and De Nicolo, 2005). The model of

\footnotetext{
${ }^{5}$ The ECB bank lending surveys are available at https://www.ecb.europa.eu/stats/money/surveys/lend/html/index.en.html
} 
Martinez-Miera and Repullo (2010) combines these opposite views and proposes a U-shaped relationship between competition and the risk of bank failure.

Empirical studies report U-shaped, inverse U-shaped, positive and negative relationships between competition and risk (Jiménez et al., 2013; Kick and Prieto, 2015; Tabak et al., 2012). Berger et al. (2009) illustrate how different measures of competition and risk can explain the divergent results. Fiordelisi and Salvatore (2014) study the relationship between competition and risk using data on European cooperative banks and find that competition increases stability.

Risk-taking behavior during normal periods can affect realized risks and thus willingness and ability to lend during crises. Jiménez and Saurina (2006) describe how competition can reduce the net interest margin and profitability of banks, thus encouraging increased volumes at the expense of quality. This does not necessarily lead to problem loans in the short run or during normal periods, allowing strong loan growth to continue. However, this can cause greater losses if the economy is affected by a crisis.

Appetite for risk can also change during crises. Bernanke et al. (1996) develop a model for socalled "flight to quality" behavior, which means that during bad periods, the relative decline in lending is greater for borrowers with high agency costs. Their empirical analysis supports the theory. Albertazzi and Marchetti (2010) examine this theory using Italian data during the recent financial crisis. They find that large and low capitalized banks began to grant relatively fewer loans to riskier firms.

\section{Funding structure and costs}

When banks also compete for deposits, the competitive environment can affect the funding structure and costs. The market power hypothesis proposes lower deposit rates in more concentrated markets. The empirical evidence supports this view (e.g., Berger and Hannan, 1989; Hannan and Prager, 2004; Hannan, 1997). There is little empirical evidence on how competition can affect banks' funding structures. Craig and Dinger (2013) describe how tight deposit competition 
increases deposit rates and thus incentives to resort to wholesale funding. However, they do not examine how competition affects the relative shares of deposit and wholesale funding. Instead, they explore the relationship between deposit market competition and risk-taking and find that fiercer competition increases the risks of banks.

According to many previous studies, the bank funding structure played a significant role in lending behavior during the recent financial crisis. Banks with a relatively large share of wholesale funding and, thus, a small share of core deposits were the most vulnerable to the freeze in global money markets and reduced lending to a greater extent (e.g., Ivashina and Scharfstein, 2010; Iyer et al., 2014).

\section{Relationship banking}

An essential aspect of banking and lending decisions is asymmetric information between lender and borrower. Banks develop close relationships with customers to ease such informational asymmetries (Boot, 2000). According to the information hypothesis, high bank competition can weaken banks' incentives to invest in soft information and, thus, relationship building. This mechanism entails reduced loan availability in more competitive markets (Petersen and Rajan, 1995). In contrast, the model of Boot and Thakor (2000) suggests that competition encourages relationship lending because it enables banks to maintain satisfactory prices in competitive markets. Empirical studies support both hypotheses (see Degryse et al., 2009, pp. 119-120).

The theoretical and empirical literature indicates that relationship banking plays a particular role during crises. The model of Bolton et al. (2013) suggests that relationship banking diminishes the effects of a crisis on lending. Relationship banks charge higher interest margins during normal periods but do not change their loan terms to the extent that transaction banks do during crises. Empirical analyses indicate that relationship banking diminished the overall increase in loan prices and the overall decrease in loan availability during the current crisis (Bolton et al., 2013; Cotugno et al., 2013; Gambacorta and Mistrulli, 2014; Puri et al., 2011). 


\section{Empirical predictions}

The past theoretical and empirical studies imply that fiercer competition decreases interest rates on loans and loosens lending standards. The previous literature also suggests that the degree of competition declines during crises. The magnitude of this decline in competition is likely to depend on the pre-crisis competitive environment: there is a greater scope for competition to decrease if it was fierce before the crisis. Consequently, if competition declines more among the banks that operated in more competitive environments before the crisis, it can be predicted that loan prices increase relatively more among these banks. Because price and other lending standards determine loan availability and credit growth, it can also be predicted that loan volumes decrease more in those markets where the pre-crisis competition was fiercer.

The previous studies consider how competitive environments can affect risk-taking, realized risks, relationship banking and funding structure and how these are relevant factors for lending behavior during crises. This means that if the effect of the crisis on lending depends on the precrisis competitive environment, the effect can also be transmitted through these factors. However, the past empirical and theoretical studies do not provide a consistent set of predictions of how the degree of competition and these other factors are related.

In sum, the effect of the pre-crisis competitive environment through the changes in the degree of competition suggests a larger increase in prices and a decrease in volumes among the most competitive banks after the onset of the crisis. However, the effects of other, more indirect, factors of the pre-crisis competitive environment are unclear. Thus, the issue is ultimately an empirical one, and a main focus of this paper is to examine the total effect of various factors of the pre-crisis competitive environment. The examination of both prices and volumes facilitate the separation of the supply effects from the demand effects (see Santos, 2011). For instance, if a larger decrease in loan volumes is combined with a larger increase in loan prices among the most competitive banks, this is consistent with the dominance of a supply shift; the dominance of a demand shift would 
indicate a larger decrease in volumes combined with a smaller increase in prices. Through an auxiliary analysis, I examine the contributions of various factors to the total effect of the pre-crisis competitive environment.

\section{Data and empirical approach}

In this section, I first describe the data used in this paper. Then, I present my empirical specifications.

\subsection{The cooperative banks of OP-Pohjola Group}

OP-Pohjola Group consists of an amalgamation of 197 independent and local cooperative banks. $^{6}$ The member banks are jointly and severally liable, but they operate independently in their own local markets. The member banks own the central institution, OP-Pohjola Central Cooperative, which controls, supervises and directs their activities. The central institution also has several subsidiaries, of which Pohjola Bank plc (Pohjola) is the most important. Pohjola is a commercial bank that acts as OP-Pohjola Group's central bank and manages the group's liquidity and international operations. It also manages corporate lending for large and mid-sized firms.

OP-Pohjola Group plays a significant role in the Finnish banking sector. Local operating areas of the member banks cover the entire area of Finland. The member banks focus primarily on small business operations, household lending and retail deposits. The Group's market share in various retail loans and deposits amounted to approximately 25 to 35 percent during the data collection period.

Although this group structure and shared business model render the banks homogeneous in some respects, the banks are also heterogeneous, particularly with respect to their size and

\footnotetext{
${ }^{6}$ This was case by the end of 2012. Bank mergers that occurred during the data period are accounted for through the use of consolidated data based on late 2012 conditions. Although the number of member banks and organizational structures has changed since then, the data description and institutional background are based on the conditions of the data period.
} 
operational environment. ${ }^{7}$ The following features are relevant to my analysis. First, cooperative banks operate in their own local markets, in which they compete primarily with other banks. ${ }^{8}$ Second, cooperative banks operate within the Central Cooperative guidelines and constraints but make independent decisions. In turn, the common limitations and targets of several economic indicators (regarding, e.g., capital adequacy and risk) are measured in a consistent manner (see also Hakenes et al., 2015). In addition, member banks receive common guidelines on lending terms (e.g., in the form of pricing models). The key issue for the empirical analysis of this paper is that even though the banks adhere to common guidelines, they ultimately operate independently, which can result, for example, in deviations from pricing model recommendations or risk/risk-taking variations within limits.

Third, the liquidity management and market funding of the cooperative banks are addressed through Pohjola. The cooperative banks have checking accounts with an overdraft facility, and they can secure short-term debt funding from Pohjola. The price of a certain short-term debt at a given time is identical for all banks and reflects the price of Pohjola's own wholesale funding. This indicates that the availability of short-term funding is not a problem for the individual cooperative banks, but the costs vary over time according to the price of wholesale funding for Pohjola. This can affect their willingness to resort to this type of funding at various times.

Finally, the cooperative business model can affect lending behaviors at various times in relation to other banks. On the one hand, this paper presents a favorable approach in that my data exclude the heterogeneous effects of the crisis on lending based on organizational forms. On the other hand, lending behaviors of other banks relative to cooperative banks can affect loan demands

\footnotetext{
${ }^{7}$ Hyytinen and Toivanen (2004) use data on the same cooperative banks to study whether the banks use their branch network to invest in monitoring and/or market power and how this affects loan interest rates and credit losses.

${ }^{8}$ The main rival banks include nationwide commercial banks, such as Nordea, Danske Bank, Aktia and Handelsbanken, local saving banks, and local cooperative banks that do not belong to OP-Pohjola Group.
} 
in cooperative banks, and this effect may depend on competitive environments. This issue is considered when interpreting the results.

\subsection{Data sources}

The bank data collected from within the OP-Pohjola Central Cooperative include detailed monthly lending information for all cooperative banks between January 2004 and October 2010. The price and volume information is available for both outstanding and new business loans, mortgages and consumer loans. The data also contain detailed balance sheet, income statement and deposit information for each cooperative bank. Additionally, the information on small business lending is complemented by loan-specific data that are available beginning in September $2008 .{ }^{9}$

The data on the branch locations of all Finnish banks come from the establishment data of the business register of Statistics Finland. Annual data between 2004 and 2010 include enterprise (bank) name and business ID, establishment (branch) name and code, municipality and zip code. Local economic data are at the municipal level and are collected from the statistical databases StatFin and Altika of Statistics Finland.

The number of the branches of all banks is assigned to each cooperative bank based on zip codes. The local economic data are combined at the municipality level, and hence, local variables are calculated based on all municipalities in which a cooperative bank operates.

\subsection{Small business lending data and dependent variables}

The corporate loans of the cooperative banks are primarily small business loans because Pohjola manages the loans for larger companies. ${ }^{10}$ The dependent variables include both price and volume measures of new business loans. The volume variable is new business loans per month

\footnotetext{
${ }^{9}$ These loan-specific data allow credit risk with internal credit ratings that are not included in the bank-specific data to be controlled.

${ }^{10}$ Based on loan-specific data between October 2008 and June 2013, 89 percent of new business loan contracts were under 250000 euros and 96 percent were under one million.
} 
divided by total assets in the previous month. More precisely, the data are on the new withdrawn loans, which primarily consist of new contracts but also include drawdowns of existing loan commitments. ${ }^{11}$ Because my interest is in the purely new lending activity, the effect of drawdowns of existing loan commitments is diminished by using the lagged value of off-balance sheet items, which include the undrawn commitments, as a control variable in the estimations. My measure better describes the changes in loan supply and demand than the change in outstanding loans used in many previous papers (e.g., Cornett et al., 2011) because the latter measure is also affected by loan repayments.

The price variable is average loan margin, which is the average margin on monthly new variable rate business loans with either the Euribor rates or banks' own prime rate as a reference rate. ${ }^{12}$ A loan margin is a commonly used measure for loan pricing in previous literature and often calculated as the average loan rate minus some market interest rate (e.g., Lepetit et al., 2008). In this paper, I can use detailed data that are used for an internal comparison of the loan margins between the products and member banks in the OP-Pohjola Group. These data enable a precise and consistent measure of pricing across the banks. ${ }^{13}$

The general volume and margin trends of cooperative banks' new business loans are presented in Figures 1 and 2. The vertical lines that appear at October 2008 denote the start of the crisis period, which is determined based on the collapse of Lehman Brothers on September 15, 2008. This event is typically viewed as the start of the global financial crisis, and many papers that

\footnotetext{
${ }^{11}$ I use the term "new loans" throughout the text, even if the precise measure is new withdrawn loans.

${ }^{12}$ The average total interest rate on small business loans is dependent on market interest rates, and it decreased during the crisis due to decreased market interest rates, despite that the margins on new loans increased.

${ }^{13}$ The loan margins and their changes over time broadly reflect the loan pricing model of the Group that is used to control pricing behavior of the member banks. The model is common to all banks and produces recommended loan margins based on several factors. However, individual banks can deviate from these recommended loan margins, which enables the examination of heterogeneous pricing behavior between the banks.
} 
use European data identify it as the start of the crisis period (Albertazzi and Marchetti, 2010; Bolton et al., 2013; Gambacorta and Mistrulli, 2014). ${ }^{14}$

[Figure 1]

[Figure 2]

\subsection{Competition measures}

Bank competition measures are typically classified based on the Traditional and New Empirical Industrial Organization (IO) literature. The traditional IO literature uses market structure measures, whereas new measures attempt to gauge market power more directly. ${ }^{15}$ Carbo et al. (2009) compare various competition measures and report that these are only weakly related. The recent literature often argues that national concentration is an inappropriate measure of bank competition (Bikker et al., 2012; Claessens and Laeven, 2004; Schaeck et al., 2009). Schaeck et al. (2009) note that if bank markets are local, national concentration measures can, in principle, be a misleading approach to gauging competition. I employ both a traditional market structure measure, the Herfindahl-Hirschman Index (HHI), and a more direct market power measure, the Lerner index, to define the competitiveness of markets. Both measures are calculated at the bank level, and a bank operating area constitutes one local market.

For the empirical analysis, I classify the banks into two groups based on either the average HHI or the average Lerner index before the crisis. A bank is in the more competitive environment if

\footnotetext{
${ }^{14}$ The subprime crisis had already started in the third quarter of 2007 , and this is often viewed as the beginning of the crisis period in studies that use US data (e.g., Cornett et al., 2011) and in studies that examine effects of subprimerelated loss exposure for European banks (e.g., Puri et al., 2011).

15 Traditional measures include, e.g., concentration ratios, number of banks or Herfindahl indices (Beck et al., 2010). The new IO measures include, e.g., the Lerner index and Panzar and Rosse H-statistics. Other competition measures employed include, e.g., the net interest margin and return on assets (see e.g., Carbo et al., 2009).
} 
its pre-crisis average of the relevant competition measure is in the first quintile. ${ }^{16}$ I employ the precrisis averages of competition measures in order to avoid endogeneity problems, as the changes in competition are part of the outcome of the crisis.

The HHI is based on the locations of branches of the cooperative banks and of all other banks in Finland. It is computed by assuming that the share of branches represents the market share, as in Degryse and Ongena (2007) and Chong et al. (2013). ${ }^{17}$ Consequently, the HHI is calculated for each cooperative bank based on the number of its branches and the number of other bank branches present in its local operating area. This is calculated at the zip code level (see Appendix A for details).

The Lerner index denotes the relative markup of price over marginal cost. In previous literature, the Lerner index is computed in various ways, depending on data availability and the study purpose. It is typically computed using the average price of bank activities based on total revenues or interest revenues and the marginal costs of total funding and operating costs, which generates a single indicator of banking activity (see e.g., Fernández de Guevara et al., 2005). Even if the Lerner index constructed in this way is based on market power on the loan/asset side, it also captures the impact of market power on the deposits/funding side through the marginal costs (see e.g., Beck et al. 2013). A more precise measurement of market power separately in the loan or deposit market requires more detailed data and consideration of the separability of the loan and deposit markets (e.g., Jiménez et al., 2013). Previous literature has used various approaches to calculate the Lerner index that are unaffected by market power in the deposit/funding market. The funding adjusted Lerner index omits funding costs in the calculation of the marginal costs (e.g.,

\footnotetext{
${ }^{16}$ Lower Lerner index and HHI values indicate fiercer competition. I use the first quantile to clearly separate more competitive local markets. In addition, I conduct robustness checks using different classification and continuous values of pre-crisis averages.

${ }^{17}$ I conduct robustness checks by modifying the normal HHI such that different bank branches have different effects on market shares because branch sizes can vary.
} 
Fiordelisi and Salvatore, 2014). Another way is to use the Lerner index such that the marginal costs consist of the market interest rate and risk premium (e.g., Jiménez et al., 2013).

I construct the Lerner index for each cooperative bank using the ratio of total interest revenues over interest-bearing assets as the price of output. In the main analysis, the marginal costs are calculated based on three input prices: the price of labor, the price of physical capital and the price of funding. (See Appendix A for details.) This single indicator of banking activity is suitable for this paper because the effect of the pre-crisis local competitive environment on lending behavior after the onset of the crisis can come partly through the pre-crisis competitive environment in the deposit market. ${ }^{18}$ It seems also that market power in the loan and deposit markets are clearly positively correlated. ${ }^{19}$

In addition, I consider the issue focusing only market power on the asset/loan side. I conduct a number of robustness checks with competition measures that are based on market power only in the loan/asset market and that are unaffected by the market power in the deposit/funding market. I use both the funding adjusted Lerner index and the simple market power measure based on the average loan rates and the market interest rate. (See Appendix A and footnote 19.) In this way, I can compare the results based on both the separation and non-separation assumptions because I cannot explicitly assume whether the loan and deposit markets are separable, and this can also differ across local markets. ${ }^{20}$

${ }^{18}$ See section 2

${ }^{19}$ I calculate simple separate measures for the market power in the loans and deposits markets and the positive correlation of the pre-crisis averages of banks is 0.31 . The variable for the market power in the deposits market is (3month Euribor-average deposit rate)/3-month Euribor) and in the loans market is ((average loan rate-3-month Euribor)/average loan rate). It is obvious that more precise measures for marginal costs, especially for loans, should include, e.g., risk premium (see Jiménez et al., 2013), but here, the purpose is just to show that the degree of market power in the deposit and loan markets are correlated.

${ }^{20}$ The banks in my data vary in terms of their funding structure and operate in different kinds of environments. 
Both the HHI and the Lerner index have disadvantages as a measure of market competitiveness, and I use these as complementary to obtain more reliable results. The Lerner index can measure the competitiveness of a bank (especially cost efficiency) in addition to or instead of market competition. Instead, because the HHI measures market concentration, it is not directly related to the competitiveness of a bank. However, as discussed above, its ability to measure market competition has been questioned in the previous literature. Lapteacru (2014) considers the theoretical differences between the HHI and the Lerner index and notes how empirical studies often do not take these differences into account and use measures interchangeably. In this paper, I do not assume that the HHI and the Lerner index measure precisely the same thing; rather, the main purpose is to identify differences across the banking markets. I assume that both measures can gauge some aspects of the local competitive environment even if they both have their own shortcomings. The previous literature based on national level data does not find a strong correlation between the Lerner index and the HHI (e.g., Carbo et al., 2009), but in my data, the correlation between these two measures is significantly positive. ${ }^{21}$

\subsection{Control variables and descriptive statistics}

I control for the key transmission channel of crisis effects on the loan supply observed in the previous literature (e.g., Iyer et al., 2014), i.e., the dependence on short-term, market-based funding, by classifying the banks into those that are most dependent and the others. This classification is based on one-year averages of the share of short-term, market-based funding of total assets before the onset of the crisis, and the most-dependent banks are those in the top quintile. This accounts for the effects of funding structures on lending during the crisis as serious problems in money markets, and thus, the difficulties banks faced in obtaining short-term, market-based funding, was a key feature of the crisis period. Even if the availability of short-term, market-based funding from the

\footnotetext{
${ }^{21}$ The positive correlation in the whole data period is 0.31 . The correlation is larger before the crisis $(0.43)$ than during the crisis (0.29).
} 
central bank, Pohjola, was similar for all cooperative banks at a certain time, the exposure of an individual bank to turbulence in money markets was dependent on the relative amount of this type of funding, as Pohjola's pricing over time reflects its own cost of wholesale funding.

I use local economic variables and province-specific time trends to control for the dynamics of loan demand. The local economic variables include the unemployment rate, the growth of sales in establishments, personal income and the growth in the number of corporations (see e.g., Adams and Amel, 2011; Keeton, 2009). I use the province-specific time trends separately for the pre-crisis and crisis periods to take into account heterogeneous changes in local demand conditions after the onset of the crisis.

I also control bank characteristics that can affect loan supply and pricing based on the previous literature (e.g., Gambacorta and Mistrulli, 2014; Jiménez et al., 2012b). Size, capitalization, liquidity and non-performing loans are commonly used bank-specific factors. Offbalance-sheet commitments are an important control in my setting because my volume measure, new loans, also includes drawdowns of existing loan commitments. I measure these control variables as follows: The capitalization variable is the regulatory capital adequacy ratio, defined as Tier 1 capital divided by total risk-weighted assets. The liquidity variable is liquid assets divided by total assets. Liquid assets consist of cash, demand deposits held by other banks (especially Pohjola) and debt securities eligible for refinancing with central banks. Bank size is measured by the logarithm of total assets. Non-performing loans are loans that have been in default for 90 days, and these are also scaled by total assets. The relative size of off-balance-sheet activity is measured by the amount of irrevocable commitments to customers divided by total assets.

\section{[Table 1]}

Table 1 shows descriptive statistics for variables used in the estimations, presented separately for the crisis period and for the period preceding the crisis. Competition and local economic variables are measured at yearly intervals, and all other variables are measured at monthly intervals. 
All 197 banks are observed from January 2004 to September 2010; thus, 15,957 monthly observations and 1,379 yearly observations were made. ${ }^{22}$ The average of new business loans divided by total assets decreased from $0.34 \%$ before the crisis to $0.28 \%$ during the crisis, and the average loan margin increased from 1.29 to 1.58 percentage points.

The average Lerner index of all banks is lower during the crisis period, which should denote increased competition. However, this may reflect problems with using the Lerner index as a competition measure in a low interest rate environment that coincides with the crisis period. This is particularly relevant if deposit funding plays a significant role and if loans have floating interest rates, which are both the case in my data. In a low interest rate environment, deposit rates can fall to lower limits, and funding costs become rigid to market interest rates, while floating loan rates continue to change in line with market interest rates. ${ }^{23}$ Because this paper examines the effect of different pre-crisis competitive environments on changes in lending behavior during the crisis, the analysis focuses on the pre-crisis averages of Lerner indices. When effects of the heterogeneous changes in the degree of competition in different pre-crisis competition environments after the onset of the crisis are examined in the auxiliary analyses, the empirical analysis is based on relative changes in Lerner indices.

\subsection{Empirical specifications}

I apply a difference-in-differences (DID) approach to analyze whether the effect of the crisis on margins and volumes of new small business loans depends on the pre-crisis competitive

\footnotetext{
${ }^{22}$ The lack of observations for some variables is attributable to months without new business lending and to missing information on individual banks.

${ }^{23}$ First, the share of deposits in the total debt funding is 91.5 percent in my data. The significant share of these deposits are current account deposits of which interest rates are typically much lower than market interest rates. Second, there is clear evidence that the net interest margin decreases significantly along with market interest rates if variable rate loans are dominant (e.g., ECB, 2015, pp. 65-68). Furthermore, it seems that the decrease in the Lerner index along with market interest rates during the crisis is not specific to my data (see e.g., Beck et al., 2013).
} 
environment. I estimate the following econometric models:

$\frac{\text { New business loans }}{\text { it }}=$

$\alpha+\beta_{1}$ Crisis $+\beta_{2}$ Comp $+\beta_{3}$ Comp x Crisis $+\beta_{2}$ Shortdebt $+\beta_{3}$ Short debt $\times$ Crisis +

$\sum_{\mathrm{j}=1}^{\mathrm{J}} \delta_{\mathrm{j}} \mathrm{X}_{\mathrm{j}, \mathrm{i}, \mathrm{t}-1}+\sum_{\mathrm{k}=1}^{\mathrm{K}} \theta_{\mathrm{k}} \mathrm{R}_{\mathrm{k}, \mathrm{i}, \mathrm{t}}+\sum_{\mathrm{l}=1}^{\mathrm{L}} \gamma_{\mathrm{l}}$ Province $_{\mathrm{l}} * \mathrm{t}_{\text {before }}+\sum_{\mathrm{l}=1}^{\mathrm{L}} \mathrm{\kappa}_{\mathrm{l}}$ Province $_{\mathrm{l}} * \mathrm{t}_{\text {crisis }}+\varepsilon_{\mathrm{it}}$,

and

Average loan $\operatorname{margin}_{i t}=\alpha+\beta_{1}$ Crisis $+\beta_{2}$ Comp $+\beta_{3}$ Comp x Crisis $+\beta_{2}$ Shortdebt +

$\beta_{3}$ Short debt x Crisis $+\sum_{\mathrm{j}=1}^{\mathrm{J}} \delta_{\mathrm{j}} \mathrm{X}_{\mathrm{j}, \mathrm{i}, \mathrm{t}-1}+\sum_{\mathrm{k}=1}^{\mathrm{K}} \theta_{\mathrm{k}} \mathrm{R}_{\mathrm{k}, \mathrm{i}, \mathrm{t}}+\sum_{\mathrm{l}=1}^{\mathrm{L}} \gamma_{\mathrm{l}}$ Province $_{\mathrm{l}} * \mathrm{t}_{\mathrm{before}}+$

$\sum_{\mathrm{l}=1}^{\mathrm{L}} \kappa_{\mathrm{l}}$ Province $_{\mathrm{l}} * \mathrm{t}_{\text {crisis }}+\varepsilon_{\mathrm{it}}$,

where $\mathrm{i}$ is the bank and $\mathrm{t}$ is the month. The Crisis dummy takes value zero for the pre-crisis period from January 2004 to September 2008. The Crisis dummy takes value one for the crisis period from October 2008 to September 2010. The Comp dummy takes value one for the banks in the most competitive environments before the crisis and zero for the other banks.

The model is first estimated without controls, i.e., using only the Crisis and Comp dummies and their interaction term. This specification of the model allows for two differences. The first difference is a comparison between the pre-crisis period and the crisis period. This difference is captured by coefficient $\beta_{1}$, which measures the common effect of the crisis on the volumes or prices of new small business loans in both competitive environment groups. The second difference is a comparison between the banks that operated in the most competitive environments in the pre-crisis period and the other banks. Coefficient $\beta_{2}$ indicates whether loan volumes or prices were higher (or lower) in the most competitive environments before the crisis. My primary interest is in the DID estimate, i.e., in the coefficient $\beta_{3}$ of the interaction term of Crisis and Comp (cf., e.g., Dewally and 
Shao, 2014). ${ }^{24}$ This coefficient measures whether the effect of the crisis on the loan volumes and prices is different between the banks that operated in the most competitive environment before the crisis and the other banks. For example, a positive $\beta_{3}$ in equation 2 would indicate that, after the onset of the crisis, loan margins increased more (or decreased less) in the banks that operated in the most competitive environment before the crisis compared to the banks that operated in less competitive environments.

In the above simple specification that includes no controls, the identification of the effect of the pre-crisis competitive environment on how the crisis affected the loan volumes and prices relies on the assumption that the effect of the crisis on lending is independent of other local market factors and bank characteristics. This assumption is quite strong. To relax it, I consider the following controls. First, I control for (potentially) heterogeneous changes in local loan demand conditions by using a vector of local market factors, denoted $\mathrm{R}$ above, and province-specific time trends. ${ }^{25}$ The province-specific time trends are separately specified for the pre-crisis and crisis periods such that $t_{\text {before }}=1, \ldots, 57$ from January 2004 to September 2008 and zero otherwise and such that $\mathrm{t}_{\text {crisis }}=1, \ldots, 24$ from October 2008 to September 2010 and zero otherwise. Moreover, I control for the effects of a bank's dependence on short-term funding by using the Short debt dummy and its interaction with the Crisis dummy. The Short debt dummy takes value one for the banks that were most dependent on short-term, market based funding at the onset of the crisis and is zero for the other banks.

In addition, the DID approach relies on the assumption that trends in loan volumes and prices would have been similar in the more and less competitive environments in the absence of the crisis. This is the parallel trend assumption. This assumption cannot be directly tested, but the evolution of

\footnotetext{
${ }^{24}$ In terms of the pure DID setting, where it is assumed that the treatment affects only one of the groups, the treatment can be interpreted as the combined effect of the crisis and pre-crisis competitive environment.

25 The number of provinces is 19 .
} 
the average volumes and margins in the more and less competitive environments before the crisis support the assumption, particularly for the margins (see Appendix B). In addition, the inclusion of the vector of bank-specific factors $(\mathrm{X})$ relaxes the parallel trends assumption: it ought to hold conditional on the bank-specific factor being in the model.

Finally, I estimate the model with bank and time fixed effects. The bank fixed effects control for unobservable, time-invariant differences between banks and their local environments. ${ }^{26}$ The time (year-month) fixed effects control for the common changes in the lending environment, such as changes in monetary policy and new regulatory initiatives. In particular, this specification captures the effect of the level of the market interest rate on the loan margin. ${ }^{27}$

A relevant issue for the working of the DID methodology is how stable the classification of the banks into the more and less competitive groups is over time. According to my classification, a bank belongs to the same group of banks over the whole sample period: the classification of banks into the most competitive and the others is based on the pre-crisis averages of competition measures, measured for the five-year period just before the crisis. This choice follows directly from my aim to examine how the effect of the crisis depends on the pre-crisis competitive environment. I have also checked that the two groups were reasonably stable before the crisis by exploring how their composition would change if the classification is performed yearly. ${ }^{28}$ It is important to note that if the composition of the banks in the two groups were allowed to change after the onset of the

\footnotetext{
${ }^{26}$ The Comp and Short debt dummies are not used when bank fixed effects are included because they are constant for individual banks over time.

${ }^{27}$ This is especially important if the loan and deposit markets are separated and the market interest rate is the most important element of the marginal costs when calculating market power in the loan market. The separation of the loan and deposit markets and the importance of the market interest rate in the marginal costs likely differ across banks due to, e.g., the differences in their funding structure.

${ }^{28}$ In the case of the Lerner index, the yearly first quintiles include 74-85 percent of the banks classified into the most competitive environment. In the case of the HHI, the annually most competitive banks remain completely the same.
} 
crisis, this could cause an endogeneity problem, as changes in the degree of competition is part of the outcome of the crisis.

\section{Empirical analysis}

This section presents the results of the main empirical analysis regarding the effect of the precrisis competitive environment on the changes in volumes and prices of small business loans after the onset of the financial crisis. In addition, this section includes several robustness checks.

\subsection{Main results}

[Table 2]

Table 2 presents the bivariate results of the mean DID estimates of the volumes and margins of new business loans for the banks that operated in the most competitive environments before the crisis and for the other banks. ${ }^{29}$ The classification of the banks into two groups is based on the precrisis average of the Lerner index in panels $\mathrm{A}$ and $\mathrm{C}$ and the pre-crisis average of the $\mathrm{HHI}$ in panels $\mathrm{B}$ and D. The volume of new business loans relative to total assets was, on average, significantly lower during the crisis than before the crisis in both groups (panels A and B of Table 2). More importantly, the interaction terms of the pre-crisis competitive environment and the crisis, i.e., DID estimates, are negative and statistically significant. Whereas the average of new business loans divided by total assets of the previous month decreased by $17 \%(0.411 \rightarrow 0.340)$ and $19 \%(0.389$ $\rightarrow 0.315$ ) among the most competitive banks based on the Lerner index and HHI, respectively, the decline was $15 \%(0.297 \rightarrow 0.253)$ and $14 \%(0.302 \rightarrow 0.258)$ for the other banks, respectively.

The margins of new business loans increased significantly after the onset of the financial crisis (panels $\mathrm{C}$ and $\mathrm{D}$ of Table 2). Before the crisis, the average loan margin was significantly lower among the banks that operated in the most competitive environment than among the other

\footnotetext{
${ }^{29}$ Analogous results to those in Table 2 and when the classification is based on the Lerner index are presented in Figures B.1 and B.2 in Appendix B.
} 
banks, but the difference between these groups nearly vanished after the onset of the crisis. The results indicate that the average loan margin of the pre-crisis most competitive banks increased by 43 or 40 basis points and by 24 basis points among the other banks. These differences, i.e., the DID estimates, are also statistically significant.

[Table 3]

Table 3 presents results for volumes (Panel A) and prices (Panel B) when the effect of dependence on short-term, market-based funding is considered and when bank-specific and local environmental controls are included (columns 2-3). The estimates presented in column 4 also include bank and time fixed effects. The classification of the banks into the competitive environment groups is based on the Lerner index in these estimations. Column 5 presents the results obtained when the HHI is used to define the pre-crisis competitive environment, and all controls and bank and time fixed effects are included. Standard errors are clustered at the bank level to account for potential serial correlations, which are particularly critical in the case of DID estimation (Bertrand et al., 2004).

Panel A of Table 3 indicates that, in the volume regressions, the interaction term coefficient of the pre-crisis competitive environment and crisis dummies remains negative and fairly stable, but it becomes statistically insignificant when controls are included and when the competitive environment classification is based on the Lerner index. ${ }^{30}$ Instead, the coefficient of this interaction term is negative and statistically significant when the pre-crisis competitive environment is classified based on the HHI and when all controls are included. These results suggest that volume declines after the onset of the crisis were greater among the banks that operated in the most competitive environments before the crisis than among the other banks. The interaction coefficient

\footnotetext{
${ }^{30}$ The estimate of interest is the coefficient of the interaction term for all specifications. For example, the crisis dummy estimate becomes insignificant in columns 3-5, but this estimate no longer has the same meaning as in the specifications of columns 1 and 2 because the common effects of the crisis period are also captured by separate province-specific time trends for the pre-crisis and crisis periods and by time fixed effects.
} 
values roughly range between 0.02 and 0.03 , or at approximately half of the average decrease for all banks after the onset of the crisis (see Table 1), although these estimates are not statistically robust in every specification.

Panel B of Table 3 shows, that in the margin regressions, the interaction term coefficient of the pre-crisis competitive environment and crisis dummies is positive and does not change substantially when controls are added and that it is also statistically significant in all specifications. This result remains when the HHI is used to classify the pre-crisis competitive environment. This finding confirms the bivariate analysis results, which show that the new small business loan margin increases after the onset of the crisis were greater among the banks that operated in the most competitive environments before the crisis than among the other banks. The average margin increases are approximately 20 or 13 basis points higher among the banks that operated in the most competitive environments, according to the Lerner index and HHI, respectively. The economic relevance becomes evident when this finding is compared with the average increase among all banks of 29 basis points (Table 1).

\subsection{Robustness checks}

I conduct various robustness checks to consider possible problems in the main analysis. The difference-in-difference analysis based on the two groups, namely, the banks in more and less competitive environments before the crisis, assumes a discontinuous effect of the competition measures because the variables only take a value of one or zero. Now, I use continuous values instead of dummies for the competition measures and keep the estimations otherwise unchanged.

The results are reported in Table 4. They are comparable to Table 3 and indicate that my main results are robust to the use of continuous competition variables. ${ }^{31}$

[Table 4]

\footnotetext{
${ }^{31}$ The additional sixth column not present in Table 3 omits an observation if the pre-crisis HHI average is equal to one. These omitted observations are primarily of very small banks.
} 
When estimating volumes, the interaction term coefficients of the crisis and the pre-crisis averages of the competition measures are positive and statistically significant in all specifications (Panel A of Table 4). Because a greater Lerner index and HHI value denotes less competition, these positive interaction term coefficients denote that the decline in new small business loans after the onset of the crisis was smaller among banks that operated in less competitive environments before the crisis. Evaluated at the tenth (0.169) and ninetieth (0.384) percentiles of the average pre-crisis value of the Lerner index and based on the coefficient of the final model in the fourth column, the decline in the loan volume measure was 0.03 percentage points lower in the least competitive environments than it was in the most competitive environments. The corresponding evaluation based on the HHI as a competition measure in the sixth column also shows a 0.03 percentage point difference. The average decrease for all of the banks was 0.06 percentage points (see Table 1).

In the margin estimations, the interaction term coefficients of the crisis and the pre-crisis average of competition measures are negative and highly statistically significant in all specifications, thereby denoting a greater increase in the loan margins of banks that operated in more competitive environments before the crisis (Panel B of Table 4). Evaluated for the tenth and ninetieth percentiles of the average pre-crisis value of the Lerner index and based on the coefficient shown in the fourth column, the increase in loan margins was 22 basis points lower in the least competitive environments than in the most competitive environments. The difference amounts to 11 basis points when the evaluation is based on the average pre-crisis values of the HHI in column 6. The average increase for all banks was 29 basis points (see Table 1).

I also estimate the DID model for two groups such that the classification of the most competitive environments is based on the lowest third of the values of average pre-crisis competition measures rather than those of the first quintile. I find that the interaction term coefficients of the crisis and the pre-crisis competitive environment change only marginally. In the case of volumes, the effect is statistically insignificant when the Lerner index is used as the 
classification variable and is significant when HHI is used. The interaction term coefficients of the pre-crisis competitive environment and crisis dummies are generally slightly smaller.

While crisis period identification forms an essential element of the analysis, the length of this period is not definitive. Hence, I conduct a robustness test using a one-year/12-month crisis period instead of the two-year period that is used in the primary analysis. The results are largely similar, as the estimates of the interaction terms are only slightly lower than those of the primary analysis and are more robust for margins than for volumes.

I define the modified HHI based on weighted branches of various banks as an alternative concentration measure in Appendix A, and I conduct robustness tests using this in place of the normal HHI. The results based on this modified HHI are consistent with the results based on the normal HHI, although the effect of the pre-crisis competitive environment on volume changes after the onset of the crisis is not as statistically significant as shown in the primary analysis.

Finally, I conduct robustness checks based on the measures of market power in the loan/asset market that are unaffected by market power in the deposit/funding market. I use the funding adjusted Lerner index and the simple market power measure for the loan market defined in section 3.4 and estimate the same models as in Tables 2-4. In the margin regressions, the estimates of the interaction terms are statistically significant and slightly lower than those of the primary analysis. In the volume regressions, the effects of the pre-crisis competitive environment are largely similar when the simple market power measure is used but are insignificant with the adjusted Lerner index. In sum, the various robustness checks support the results of the primary analysis, especially regarding the results of the price changes.

\section{Discussion and auxiliary analysis}

This section discusses the results of the main empirical analysis. In addition, the section includes an auxiliary analysis that further examines various explanations behind the main results. 


\subsection{Discussion of the main results}

The results indicate that the average margins of new business loans were lower before the crisis in more competitive local markets, which supports the market power hypothesis (e.g., Hannan, 1997). More important for the purpose of my study, the increase in average loan margins after the onset of the crisis was significantly greater in banks that operated in more competitive environments before the crisis. This result suggests that the pre-crisis competitive environment can explain the heterogeneous effects of the crisis on loan prices, in addition to factors such as loan losses and liquidity that are considered in the previous literature (Gambacorta and Mistrulli, 2014; Santos, 2011).

The results also reveal that the volumes of new business loans decreased to a greater extent in more competitive environments after the onset of the crisis, but this result is not as statistically robust as that for loan prices. In conjunction with the results concerning loan prices, this suggests that banks that operated in more competitive environments before the crisis reduced their loan supply to a greater extent after the onset of the crisis. If the effect of demand shock was a dominant factor behind the larger decrease in loan volumes in more competitive environments, this should be reflected by a smaller increase in loan prices. Hence, the results indicate how differences in precrisis competitive environments can explain the heterogeneous changes in loan supply in addition to factors, such as funding problems and loan losses, considered in the previous literature (e.g., Iyer et al., 2014; Puri et al., 2011). However, this interpretation must be considered with caution, as I cannot completely control for loan demand or consider lending standards other than price due to data limitation, and the results for loan volumes are not very robust.

The results are based on a unique dataset and period, and thus, generalization issues are of particular relevance. First, the results concerning the changes in loan volumes might be affected by the lending behavior of the cooperative banks related to other banks in the same local market due to 
differences in organizational forms. ${ }^{32}$ Second, it is a relevant question how the results apply to other countries and loan markets. It is obvious that more empirical research is needed to better understand the role of different competitive environments in heterogeneous effects of crises. This paper argues how the effect of competitive environments on responses to crises can come through various factors, whose contributions are next analyzed via auxiliary analyses.

\subsection{Auxiliary analyses of the competitive environment effects}

I explore possible economic mechanisms for the study finding that, after the onset of the crisis, volumes and prices of business loans changed more in the banks that operated in more competitive environments before the crisis. First, I examine the effect of the changes in the degree of competition. I then tentatively examine the role of the relationship between competitive environments and funding structures. Finally, I examine whether changes in risks can explain the main results. I am unable to consider the role of relationship lending in different competitive environments due to data limitations.

I consider the changes in the degree of competition by comparing the average Lerner index values between competitive environment groups used in the main analysis before and after the crisis. I also use the interest rate spread, i.e., the difference between the average interest rate on new loans and the average deposit rate, as a complementary measure to approximately capture the combined effect of loan and deposit competition. To complete a more detailed examination, I

\footnotetext{
${ }^{32}$ For a discussion of the effects of the cooperative business model on lending behavior during the crisis, see, e.g., Groeneveld and Vries (2009) and EACB (2010). In general, cooperative banks seemed to be more resilient to the crisis than other kinds of banks (Ferri et al., 2014). OP-Pohjola Group's market share of business loans in Finland as a whole increased from 26.8 percent to 29.2 percent between 2008 and 2010, which suggests that at least some rival banks increased prices, tightened their lending standards and/or increased rationing to a greater extent than the cooperative banks. This could mean shifts of customers to the cooperative banks. Thus, increased loan prices and possibly tightened lending standards would not have affected the reduction in loan volumes to such an extent as in the absence of different reactions of different banks. In particular, this effect might be greater in local markets with more rival banks.
} 
compare variations in the average margins of new mortgages and consumer loans and the average interest rates of current account, saving and new term deposits.

\section{[Table 5]}

Table 5 shows that after the onset of the crisis, the differences in both competition measures and the prices of various types of deposits and loans diminished between the banks that operated in the most competitive environments before the crisis and the other banks. The DID estimates are also statistically significant, but not in the case of saving deposits. This finding suggests that after the onset of the crisis, the degree of (price) competition leveled off among different local markets and resulted in a greater increase in the loan margins of banks that operated in more competitive environments before the crisis. This result indirectly supports Ruckes' (2004) theory on decreasing price competition in bust periods. ${ }^{33}$ I cannot directly examine how competition changed overall after the onset of the crisis, due to problems associated with uses of the Lerner index as a competition measure in a low interest rate environment. ${ }^{34}$

The relation between competitive environments and dependence on short-term, market-based funding is considered based on the following observations. First, my main analysis results show (Tables 3 and 4) that estimates of pre-crisis competitive environment effects on loan volumes decrease when a variable that measures dependence on short-term, market-based funding is included in the analysis. Second, Table 5 shows that the data also support the market power hypothesis for deposit rates. This finding complements the findings of previous studies (e.g., Hannan and Prager, 2004; e.g., Hannan, 1997). Third, Table 5 shows that the shares of short-term, market-based funding of total assets were, on average, larger among the banks that operated in the most competitive environments before the crisis than among the other banks, and that this

\footnotetext{
${ }^{33}$ The alternative interpretation would mean that competition increased after the onset of the crisis and more so in local environments that were less competitive before the crisis. This interpretations is not very convincing because, for example, margins of various loans increased significantly during the crisis.

${ }^{34}$ For a further discussion of this issue, see section 3.4.
} 
difference declined after the onset of the crisis. This finding tentatively suggests that competition can increase the share of short-term funding other than deposit funding, and it supports the few findings published on the issue, which also refer to this mechanism (see Craig and Dinger, 2013). However, the effect of competition on funding structures and, thus, on bank vulnerability to various funding shocks, requires further analysis.

Finally, credit risk and thus credit ratings constitute an important aspect of loan pricing, and changes in the credit ratings of small business customers can reflect changes in risk-taking and in the overall riskiness of small businesses. The bank-specific data used in the main analysis do not include credit rating information, but I can exploit the loan-specific data with internal credit ratings for the shorter period from September 2008. I calculate the average credit ratings of outstanding business loans for each cooperative bank at the start and end of the crisis period. In addition, I estimate the effect of competitive environments on loan margins at the loan level and thus control risks based on internal credit ratings. I also control loan sizes, which serve as a key element of loan pricing. Because I only use data for the period following September 2008, I first estimate a crosssectional regression on the margins of the entire stock of business loans at the start of the crisis period. Second, I estimate the regression on margins of new business loans for the crisis period using monthly fixed effects. The corresponding results are presented in Table 6.

[Table 6]

The results shown in panel A of Table 6 indicate that the average credit rating of small businesses is, on average, lower (better) for the group of the most competitive banks both in September 2008 and September 2010. However, the difference in average credit ratings at the start of the crisis is not statistically significant. The average credit ratings of outstanding business loans were slightly higher in September 2010 than they were in September 2008 in both competitive environment groups, which illustrates that the average credit risks increased after the onset of the crisis. Although the change in difference, i.e., DID estimate, is not statistically significant, these 
results indicate that, if anything, credit risks increased to a greater extent after the onset of the crisis in banks that operated in less competitive environments before the crisis. This finding has two implications. ${ }^{35}$ First, changes in the riskiness of business loans do not appear to explain more significant increases in loan margins in more competitive environments. Second, while I cannot control for changes in the riskiness of loan applicants, the greater difference in average credit ratings between the competitive environment groups at the end of the crisis could imply that the banks that operated in the most competitive environments before the crisis limited loan supply to the most risky businesses to a greater extent than the other banks. This finding suggests that "flight to quality" processes during the crisis might depend on the pre-crisis competitive environment, thus contributing to previous literature that has considered, for example, the effect of bank size and capitalization on changes in risk-taking tendencies during the crisis (Albertazzi and Marchetti, 2010).

The results shown in panel $\mathrm{B}$ of Table 6 confirm that the greater increase in loan margins after the onset of the crisis among the banks that operated in the most competitive environment before the crisis is not attributable to changes in risks. According to the estimates, at the start of the crisis, the loan margins are 12 and 8 basis points lower in the group of banks that operated in the most competitive environment before the crisis based on the Lerner index and HHI, respectively. ${ }^{36}$ During the crisis, margins of new business loans are 6 basis points higher for this same group of banks. Differences between the estimates of the pre-crisis competitive environment indicator

\footnotetext{
${ }^{35}$ Note that the datasets used in the main analysis and this credit risk analysis are not fully comparable, but the purpose is to provide approximate evidence.

${ }^{36}$ These loan-level data are also advantageous in that they enable one to exclude withdrawals of existing credit limits and to directly analyze new loan contract margins.
} 
variables for the start of the crisis and for the entire crisis period closely reflect the estimates of the interaction terms shown in Table $3 .^{37}$

\section{Conclusion}

In this paper, I examined whether the effects of the financial crisis on the volumes and prices of small business loans depended on the pre-crisis local competitive environment. Using detailed data on Finnish cooperative banks, I found that the volumes of new small business loans relative to total assets decreased and that the average loan margins increased after the onset of the crisis. More importantly, both changes were greater among the banks that operated in more competitive local environments before the crisis. The results are more robust for the loan margins and they indicate that relative to the banks operating in the less competitive environments, the increase in the average margin of new business loans was almost twice as large among the banks in the most competitive environments. These results suggest that the pre-crisis competitive environment is a relevant but previously overlooked factor for the transmission of the effects of crises.

I also examined possible reasons for the relationship between the pre-crisis competitive environment and changes in the prices and volumes of small business loans after the onset of the financial crisis. The results suggest that competition changed heterogeneously in different pre-crisis competitive environments such that differences in the degree of competition between more and less competitive environments leveled off after the onset of the crisis. This differential change appears to explain the greater changes in margins and volumes among the banks that operated in more competitive environments before the crisis. Risks and risk-taking did not differ significantly across different pre-crisis competitive environments and, if anything, should have resulted in a smaller increase in loan margins in the more competitive environments. Funding structures were somewhat

\footnotetext{
${ }^{37}$ Based on the Lerner index, 0.184(0.062+0.122), and based on the HHI, 0.133(0.056+0.077). The interaction terms in the final specifications in panel B of Table 3 are 0.195 and 0.129 , respectively.
} 
different, such that the banks in more competitive environments were more dependent on marketbased funding at the onset of the crisis, and these banks decreased their loan volumes to a greater extent during the crisis. This result tentatively supports an indirect effect of the pre-crisis competitive environment.

Overall, the results indicate that the local competitive environment can serve as a significant factor in determining heterogeneous effects of the crisis on small business lending. The results also further our awareness of channels through which the crisis affected bank lending. Finally, the results highlight the potential role of competition in procyclical lending, which currently constitutes a central issue of bank supervision and regulation.

\section{Appendix A. Measurement of the degree of competition}

\section{Branch HHI}

The HHI based on the number of branches is calculated in the following manner:

Branch $\mathrm{HHI}_{\mathrm{bt}}=\sum_{\mathrm{i}=1}^{\mathrm{n}}\left(\text { Number of Branches } \mathrm{s}_{\mathrm{ibt}} / \text { All branches } \text { bt }_{\mathrm{bt}}\right)^{2}$,

where $b$ is the operating area of an individual cooperative bank, $i$ refers to various banks and $t$ is the year.

I perform robustness checks by modifying the normal HHI such that different bank branches have different effects on market share, as branch sizes vary. Branch weights are based on total bank business loan market shares for Finland relative to the total number of branches and are calculated in the following manner:

Branch weight $_{\text {it }}=$

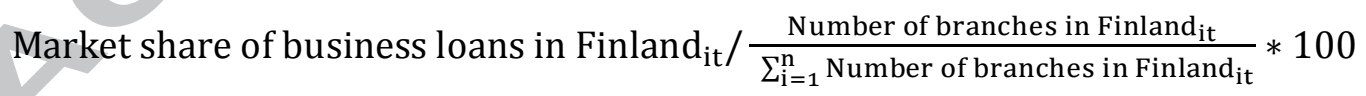

This means that the branch weight of a bank is greater than 1 if its market share of business loans is larger than its share of branches and vice versa. Now, the weighted branch HHI can be calculated as: 
Weighted Branch $\mathrm{HHI}_{\mathrm{bt}}=$

$\sum_{\mathrm{i}=1}^{\mathrm{n}}\left(\text { Branch weight }_{\mathrm{it}} \times \text { Number of Branches }_{\mathrm{ibt}} / \text { All weighted } \text { branches }_{\mathrm{bt}}\right)^{2}$.

\section{Lerner index}

The Lerner index is defined by:

Lerner $_{i t}=\frac{\mathrm{P}_{\mathrm{it}}-\mathrm{MC} \mathrm{C}_{\mathrm{it}}}{\mathrm{P}_{\mathrm{it}}}$

where $P_{i t}$ is the price of output and $M C_{i t}$ is the marginal cost. The price of output can be calculated in various ways depending on the data and research objective, and here, it is interest revenues to interest-bearing assets. The marginal costs are derived by first estimating the translog cost function: $\ln \operatorname{Cost}_{i t}=$

$\beta_{0}+\beta_{1} \ln Q_{\mathrm{it}}+\frac{1}{2} \beta_{2} \ln \mathrm{Q}_{\mathrm{it}}^{2}+\sum_{\mathrm{k}=1}^{3} \gamma_{\mathrm{k}} \ln \mathrm{W}_{\mathrm{k}, \mathrm{it}}+\frac{1}{2} \sum_{\mathrm{k}=1}^{3} \delta_{\mathrm{k}} \ln \mathrm{Q}_{\mathrm{it}} \ln \mathrm{W}_{\mathrm{k}, \mathrm{it}}+$

$\frac{1}{2} \sum_{\mathrm{k}=1}^{3} \sum_{\mathrm{j}=1}^{3} \theta_{\mathrm{kj}} \ln \mathrm{W}_{\mathrm{k}, \mathrm{it}} \ln \mathrm{W}_{\mathrm{j}, \mathrm{it}}+\propto_{i}+\gamma_{t}+\varepsilon_{\mathrm{it}}$,

where Cost denotes total costs, $Q$ interest-bearing assets, $W_{1}$ the price of labor (labor costs to the number of employees), $W_{2}$ the price of physical capital (other costs to total assets) and $W_{3}$ the price of funding (interest costs to interest-bearing liabilities). Then, the marginal costs are calculated by using the estimates and the following equation:

$$
\mathrm{MC}_{\mathrm{it}}=\frac{\operatorname{Cost}_{\mathrm{it}}}{\mathrm{Q}_{\mathrm{it}}}\left[\widehat{\beta_{1}}+\widehat{\beta_{2}} \ln \mathrm{Q}_{\mathrm{it}}+\sum_{\mathrm{k}=1}^{3} \widehat{\delta_{\mathrm{k}}} \ln \mathrm{W}_{\mathrm{k}, \mathrm{it}}\right]
$$

I perform robustness checks using the funding adjusted Lerner index that does not include the price of funding and is thus unaffected by market power in the deposit market. Now, the marginal costs are based on the slightly modified translog cost function:

$$
\begin{aligned}
& \ln \operatorname{Cost}_{\mathrm{it}}= \\
& \beta_{0}+\beta_{1} \ln \mathrm{Q}_{\mathrm{it}}+\frac{1}{2} \beta_{2} \ln \mathrm{Q}_{\mathrm{it}}^{2}+\sum_{\mathrm{k}=1}^{2} \gamma_{\mathrm{k}} \ln \mathrm{W}_{\mathrm{k}, \mathrm{it}}+\frac{1}{2} \sum_{\mathrm{k}=1}^{2} \delta_{\mathrm{k}} \ln \mathrm{Q}_{\mathrm{it}} \ln \mathrm{W}_{\mathrm{k}, \mathrm{it}}+ \\
& \frac{1}{2} \sum_{\mathrm{k}=1}^{2} \sum_{\mathrm{j}=1}^{2} \theta_{\mathrm{kj}} \ln \mathrm{W}_{\mathrm{k}, \mathrm{it}} \ln \mathrm{W}_{\mathrm{j}, \mathrm{it}}+\propto_{i}+\gamma_{t}+\varepsilon_{\mathrm{it}}
\end{aligned}
$$

where Cost denotes total costs minus funding costs, and correspondingly only $W_{1}$ and $W_{2}$ are included in the estimation of the translog cost function and in the calculation of the marginal costs. 


\section{Appendix B. Figures depicting the average development of small business lending among}

\section{banks in more and less competitive environments}

[Figure B.1]

[Figure B.2]

\section{Acknowledgements}

I thank three anonymous reviewers, Associate Editor, Manuel Bagues, Ari Hyytinen, Juha Junttila,

Panu Kalmi, Kari Kemppainen and Jaakko Pehkonen, participants at the Allecon seminar

(Jyväskylä), Finnish Economic Association XXXVI Annual Meeting (Kuopio) and EARIE 2014

(Milan) for valuable comments. I thank Toni Honkaniemi, Arto Kuhmonen, Kirsi Saari and Ari

Saarinen for providing the bank data. Financial support from the OP-Pohjola Group's Research

Foundation is gratefully acknowledged.

\section{References}

Adams, R.M., Amel, D.F., 2011. Market structure and the pass-through of the federal funds rate. Journal of Banking and Finance 35 (5), 1087-1096.

Agarwal, S., Hauswald, R., 2010. Distance and Private Information in Lending. Review of Financial Studies 23 (7), 2757-2788.

Albertazzi, U., Marchetti, D.J., 2010. Credit Crunch, Flight to Quality and Evergreening : An Analysis of Bank-Firm Relationships After Lehman. Working paper, Bank of Italy.

Asea, P.K., Blomberg, B., 1998. Lending cycles. Journal of Econometrics 83 (1-2), 89-128.

Beck, T., Coyle, D., Dewatripoint, M., Freixas, X., Seabright, P., 2010. Bailing out the Banks: Reconciling Stability and Competition. Centre for Economic Policy Research (CEPR).

Beck, T., Jonghe, O. De, Schepens, G., 2013. Bank competition and stability : Cross-country heterogeneity. Journal of Financial Intermediation 22 (2), 218-244.

Berg, J., Rixtel, A. Van, Ferrando, A., De Bondt, G., Scopel, S., 2005. The Bank Lending Survey for the Euro Area. ECB Occasional Paper Series No. 23.

Berger, A.N., Hannan, H., 1989. The Price-Concentration Relationship in Banking. The Review of Economics and Statistics 71 (2), 291-299.

Berger, A.N., Klapper, L.F., Turk-Ariss, R., 2009. Bank Competition and Financial Stability. Journal of Financial Services Research 35 (2), 99-118.

Berger, A.N., Udell, G.F., 1998. The economics of small business finance: The roles of private equity and debt markets in the financial growth cycle. Journal of Banking \& Finance 22 (6-8), 613673. 
Bernanke, B.S., Gertler, M., Gilchrist, S., 1996. The financial accelerator and the flight to quality. The Review of Economics and Statistics 78 (1), 1-15.

Bernanke, B.S., Lown, C.S., 1991. The Credit Crunch. Brookings Papers on Economic Activity 1991 (2), 205-247.

Bertrand, M., Duflo, E., Mullainathan, S., 2004. How Much Should We Trust Differences-InDifferences Estimates? The Quarterly Journal of Economics 119 (1), 249-275.

Bikker, J.A., Shaffer, S., Spierdijk, L., 2012. Assessing competition with the Panzar-Rosse model: The role of scale, costs, and equilibrium. The Review of Economics and Statistics 94 (4), 1025 1044.

Bolton, P., Freixas, X., Gambacorta, L., Mistrulli, P.E., 2013. Relationship and Transaction Lending in a Crisis. BIS Working Papers No. 417.

Boot, A.W.A., 2000. Relationship Banking: What Do We Know? Journal of Financial Intermediation 9 (1), 7-25.

Boot, A.W.A., Thakor, A. V, 2000. Can Relationship Banking Survive Competition? The Journal of Finance 55 (2), 679-713.

Boyd, J.H., De Nicolo, G., 2005. The Theory of Bank Risk Taking and Competition Revisited. The Journal of Finance 60 (3), 1329-1343.

Carbo, S., Humphrey, D., Maudos, J., Molyneux, P., 2009. Cross-country comparisons of competition and pricing power in European banking. Journal of International Money and Finance 28 (1), 115-134.

Carbo-Valverde, S., Rodriguez-Fernandez, F., Udell, G.F., 2009. Bank Market Power and SME Financing Constraints. Review of Finance 13 (2), 309-340.

Chong, T.T.L., Lu, L., Ongena, S., 2013. Does banking competition alleviate or worsen credit constraints faced by small- and medium-sized enterprises? Evidence from China. Journal of Banking and Finance 37 (9), 3412-3424.

Claessens, S., Laeven, L., 2004. What Drives Bank Competition? Some International Evidence. Journal of Money, Credit \& Banking 36 (3), 563-583.

Cornett, M.M., McNutt, J.J., Strahan, P.E., Tehranian, H., 2011. Liquidity risk management and credit supply in the financial crisis. Journal of Financial Economics 101 (2), 297-312.

Corvoisier, S., Gropp, R., 2002. Bank concentration and retail interest rates. Journal of Banking and Finance 26 (11), 2155-2189.

Cotugno, M., Monferrà, S., Sampagnaro, G., 2013. Relationship lending, hierarchical distance and credit tightening: Evidence from the financial crisis. Journal of Banking and Finance 37 (5), 13721385 .

Craig, B.R., Dinger, V., 2013. Deposit market competition, wholesale funding, and bank risk. Journal of Banking and Finance 37 (9), 3605-3622.

Degryse, H., Kim, M., Ongena, S., 2009. Microeconometrics of Banking: Methods, Applications, and Results. Oxford University Press, New York. 
Degryse, H., Ongena, S., 2007. The impact of competition on bank orientation. Journal of Financial Intermediation 16 (3), 399-424.

Degryse, H., Ongena, S., 2005. Distance, Lending Relationships, and Competition. The Journal of Finance 60 (1), 231-266.

Dell'Ariccia, G., Igan, D., Laeven, L., 2012. Credit Booms and Lending Standards: Evidence from the Subprime Mortgage Market. Journal of Money, Credit \& Banking 44 (2-3), 367-384.

Dell'Ariccia, G., Marquez, R., 2006. Lending Booms and Lending Standards. The Journal of Finance 61 (5), 2511-2546.

Demiroglu, C., James, C., Kizilaslan, A., 2012. Bank Lending Standards and Access to Lines of Credit. Journal of Money, Credit and Banking 44 (2-3), 1063-1089.

Dewally, M., Shao, Y., 2014. Liquidity crisis, relationship lending and corporate finance. Journal of Banking and Finance 39, 223-239.

European Association of Co-operative Banks (EACB), 2010. European Co-operative Banks in the financial and economic turmoil. Research Paper, European Association of Cooperative Banks, Brussels.

European Central Bank (ECB), 2015. ECB Financial Stability Review November 2015.

European Central Bank (ECB), 2014. SME access to finance in the euro area: barriers and potential policy remedies. ECB Monthly Bulletin July 2014, 79-98.

Fernández de Guevara, J., Maudos, J., Perez, F., 2005. Market Power in European Banking Sectors. Journal of Financial Services Research 27 (2), 109-137.

Ferri, G., Kalmi, P., Kerola, E., 2014. Organizational Structure and Exposure to Crisis among European Banks : Evidence from Rating Changes. Journal of Entrepreneurial and Organizational Diversity 3 (1), 35-55.

Fiordelisi, F., Salvatore, D., 2014. Competition and financial stability in European cooperative banks. Journal of International Money and Finance 45, 1-16.

Gambacorta, L., Mistrulli, P.E., 2014. Bank Heterogeneity and Interest Rate Setting: What Lessons Have We Learned since Lehman Brothers? Journal of Money, Credit and Banking 46 (4), 753-778.

Gozzi, J.C., Goetz, M., 2010. Liquidity Shocks , Local Banks , and Economic Activity : Evidence from the 2007-2009 Crisis. Available at SSRN: http://dx.doi.org/10.2139/ssrn.1709677.

Groeneveld, H., Vries, B. De, 2009. European co-operative banks: First lessons of the subprime crisis. The International Journal of Cooperative Management 4(2), 8-21.

Hakenes, H., Hasan, I., Molyneux, P., Xie, R., 2015. Small banks and local economic development. Review of Finance 19 (2), 653-683.

Hannan, T.H., 1997. Market Share Inequality, the Number of Competitors, and the HHI: An Examination of Bank Pricing. Review of Industrial Organization 12 (1), 23-35.

Hannan, T.H., Prager, R.A., 2004. The competitive implications of multimarket bank branching. Journal of Banking and Finance 28 (8), 1889-1914. 
Hyytinen, A., Toivanen, O., 2004. Monitoring and market power in credit markets. International Journal of Industrial Organization 22 (2), 269-288.

Ivashina, V., Scharfstein, D., 2010. Bank lending during the financial crisis of 2008. Journal of Financial Economics 97 (3), 319-338.

Iyer, R., Peydro, J.-L., Da-Rocha-Lopes, S., Schoar, A., 2014. Interbank Liquidity Crunch and the Firm Credit Crunch: Evidence from the 2007-2009 Crisis. Review of Financial Studies 27 (1), 347372.

Jiménez, G., Lopez, J. A., Saurina, J., 2013. How does competition affect bank risk-taking? Journal of Financial Stability 9 (2), 185-195.

Jimenéz, G., Ongena, S., Peydró, J., Saurina, J., 2012a. Credit Supply versus Demand: Bank and Firm Balance-Sheet Channels in Good and Crisis Times. European Banking Center Discussion Paper.

Jiménez, G., Ongena, S., Peydró, J.L., Saurina, J., 2012b. Credit supply and monetary policy: Identifying the bank balance-sheet channel with loan applications. American Economic Review 102, 2301-2326. doi:10.1257/aer.102.5.2301

Jiménez, G., Saurina, J., 2006. Credit Cycles, Credit Risk, and Prudential Regulation. International Journal of Central Banking June 2006, 65-98.

Keeley, M.C., 1990. Deposit Insurance, Risk, and Market Power in Banking. The American Economic Review 80 (5), 1183-1200.

Keeton, W.R., 2009. Has Multi-Market Banking Changed the Response of Small Business Lending to Local Economic Shocks? Federal Reserve Bank of Kansas City Economic Review First Quarter 2009, 5-36.

Kick, T., Prieto, E., 2015. Bank risk and competition: Evidence from regional banking markets. Review of Finance 19 (3), 1185-1222.

Laeven, L., Valencia, F., 2013. Systemic Banking Crises Database. IMF Economic Review 61 (2), $225-270$.

Lapteacru, I., 2014. Do more competitive banks have less market power? The evidence from Central and Eastern Europe. Journal of International Money and Finance 46, 41-60.

Lepetit, L., Nys, E., Rous, P., Tarazi, A., 2008. The expansion of services in European banking: Implications for loan pricing and interest margins. Journal of Banking and Finance 32 (11), 23252335

Lown, C., Morgan, D.P., 2006. The Credit Cycle and the Business Cycle: New Findings Using the Loan Officer Opinion Survey. Journal of Money, Credit and Banking 38 (6), 1575-1597.

Martinez-Miera, D., Repullo, R., 2010. Does competition reduce the risk of bank failure? Review of Financial Studies 23 (10), 3638-3664.

Petersen, M.A., Rajan, R.G., 1995. The Effect of Credit Market Competition on Lending Relationships. The Quaterly Journal of Economics 110 (2), 407-443. 
Peydró, J.-L., Maddaloni, A., 2011. Bank Risk-taking, Securitization, Supervision, and Low Interest Rates: Evidence from the Euro-area and the U.S. Lending Standards. The Review of Financial Studies 24 (6), 2122-2165.

Puri, M., Rocholl, J., Steffen, S., 2011. Global retail lending in the aftermath of the US financial crisis: Distinguishing between supply and demand effects. Journal of Financial Economics 100 (3), $556-578$.

Rice, T., Strahan, P.E., 2010. Does credit competition affect small-firm finance? The Journal of Finance 65 (3), 861-889.

Ruckes, M., 2004. Bank competition and credit standards. Review of Financial Studies 17 (4), 1073-1101.

Santos, J.A.C., 2011. Bank Corporate Loan Pricing Following the Subprime Crisis. The Review of Financial Studies 24 (6), 1916-1943.

Schaeck, K., Cihak, M., Wolfe, S., 2009. Are competitive banking systems more stable? Journal of Money, Credit and Banking 41 (4), 711-734.

Tabak, B.M., Fazio, D.M., Cajueiro, D.O., 2012. The relationship between banking market competition and risk-taking: Do size and capitalization matter? Journal of Banking and Finance 36 (12), 3366-3381. 
Figure 1

Title:

The development of the average volume of new business loans.

Description:

The figure depicts the average trend in the volumes of new business loans among the cooperative banks of OP-Pohjola Group for the January 2004 to September 2010 period. The graph is the 12-month moving average of banks' average monthly loan volumes, measured as the percentage of new business loans divided by total assets in the previous month. 


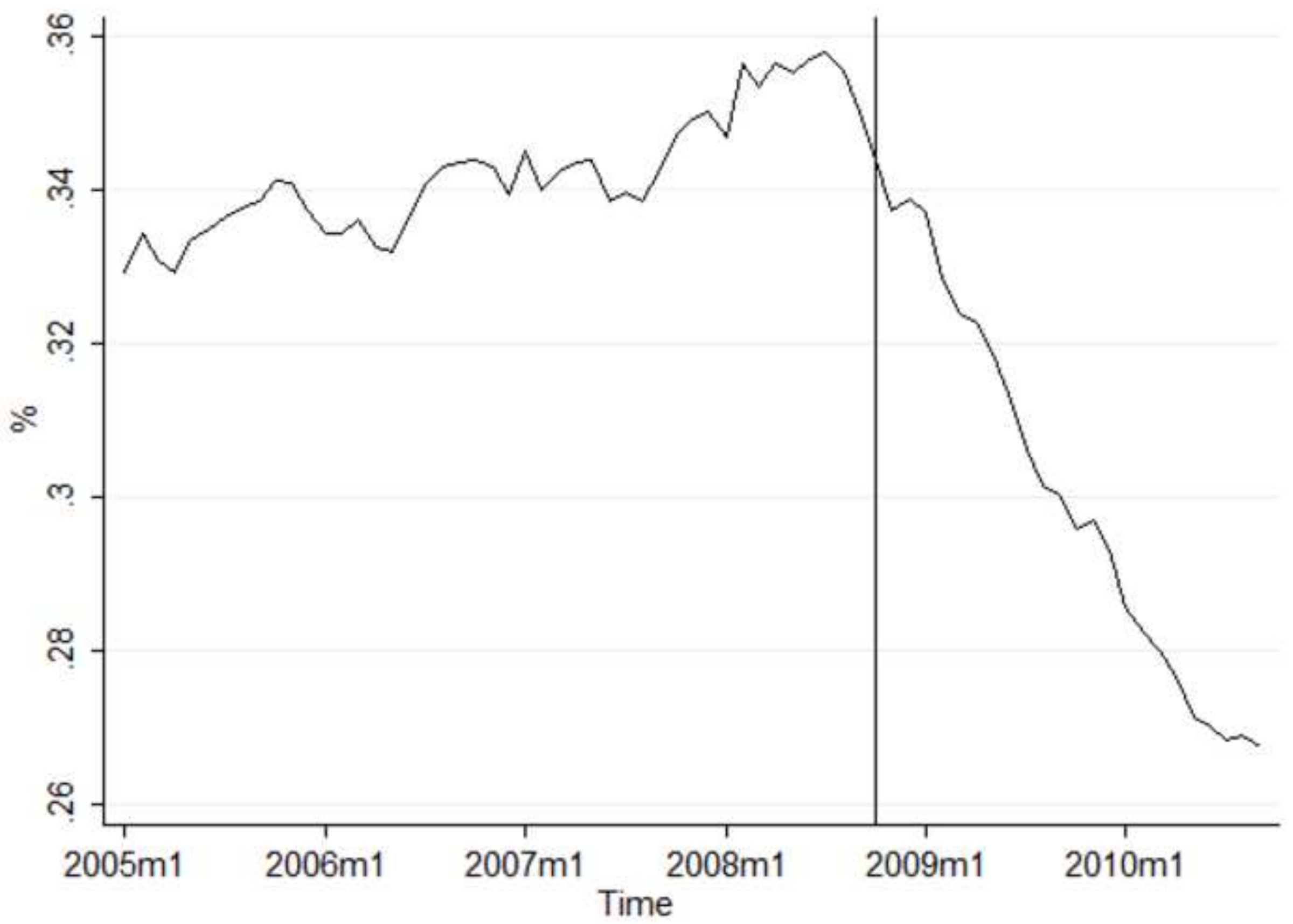




\section{Figure 2 caption}

Figure 2

Title:

The development of the average margin of new business loans

Description:

The figure depicts the average trend in the margins of new business loans among the cooperative banks of OP-Pohjola Group for the January 2004 to September 2010 period. The graph is an index of the monthly average margin of cooperative banks' new business loans. The index is used for reasons of data confidentiality.

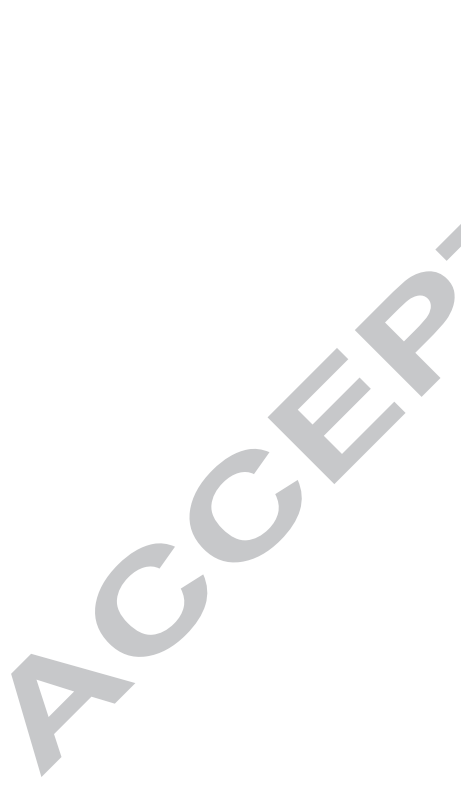




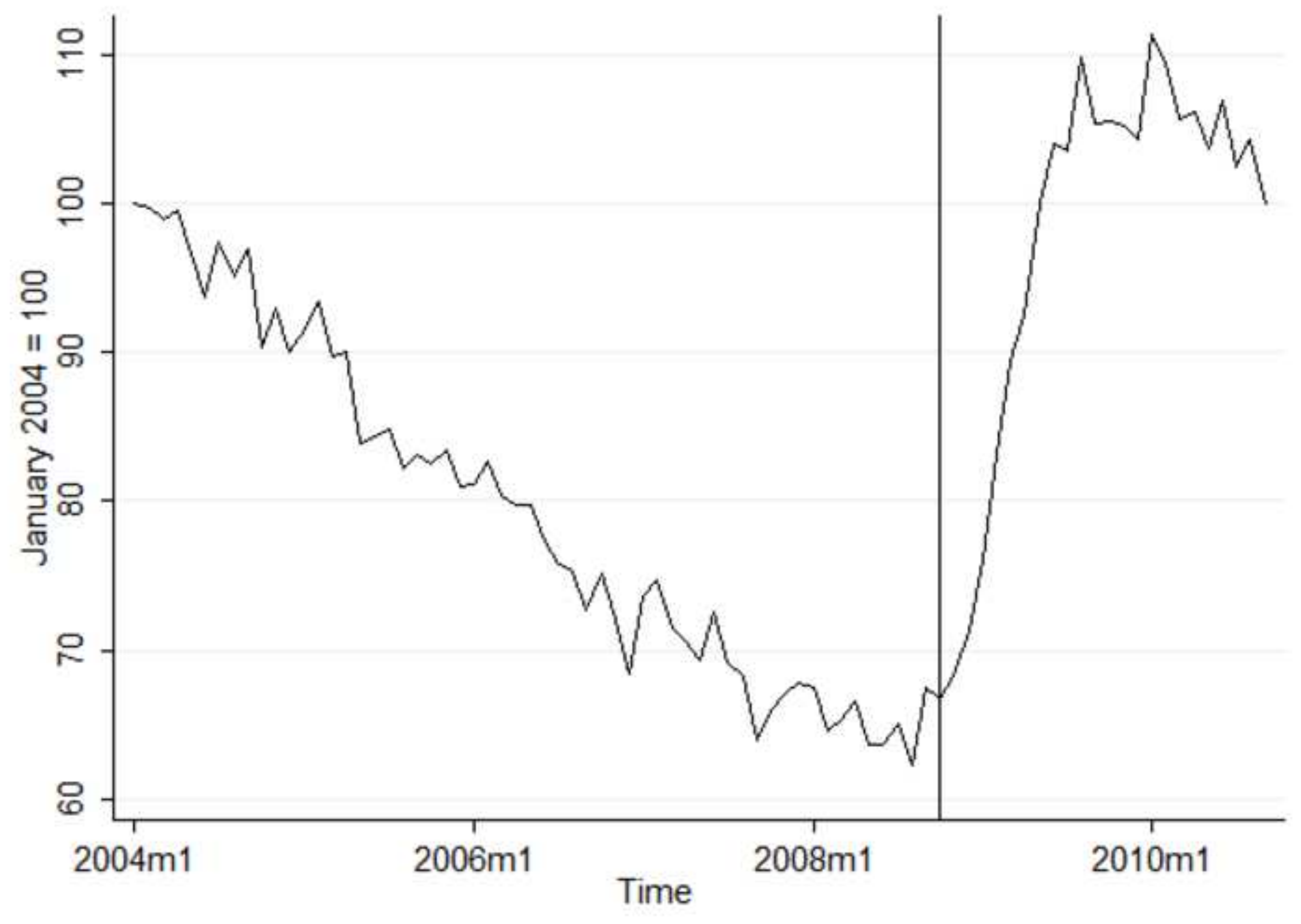




\section{Figure B.1}

Title:

The development of the average volume of new business loans.

Description:

The figure depicts the average trends in the volumes of new business loans among the banks that operated in the most competitive environments before the crisis and among the other banks. The graphs are the 12-month moving averages of banks' average monthly loan volumes, measured as the percentage of new business loans divided by total assets in the previous month. 


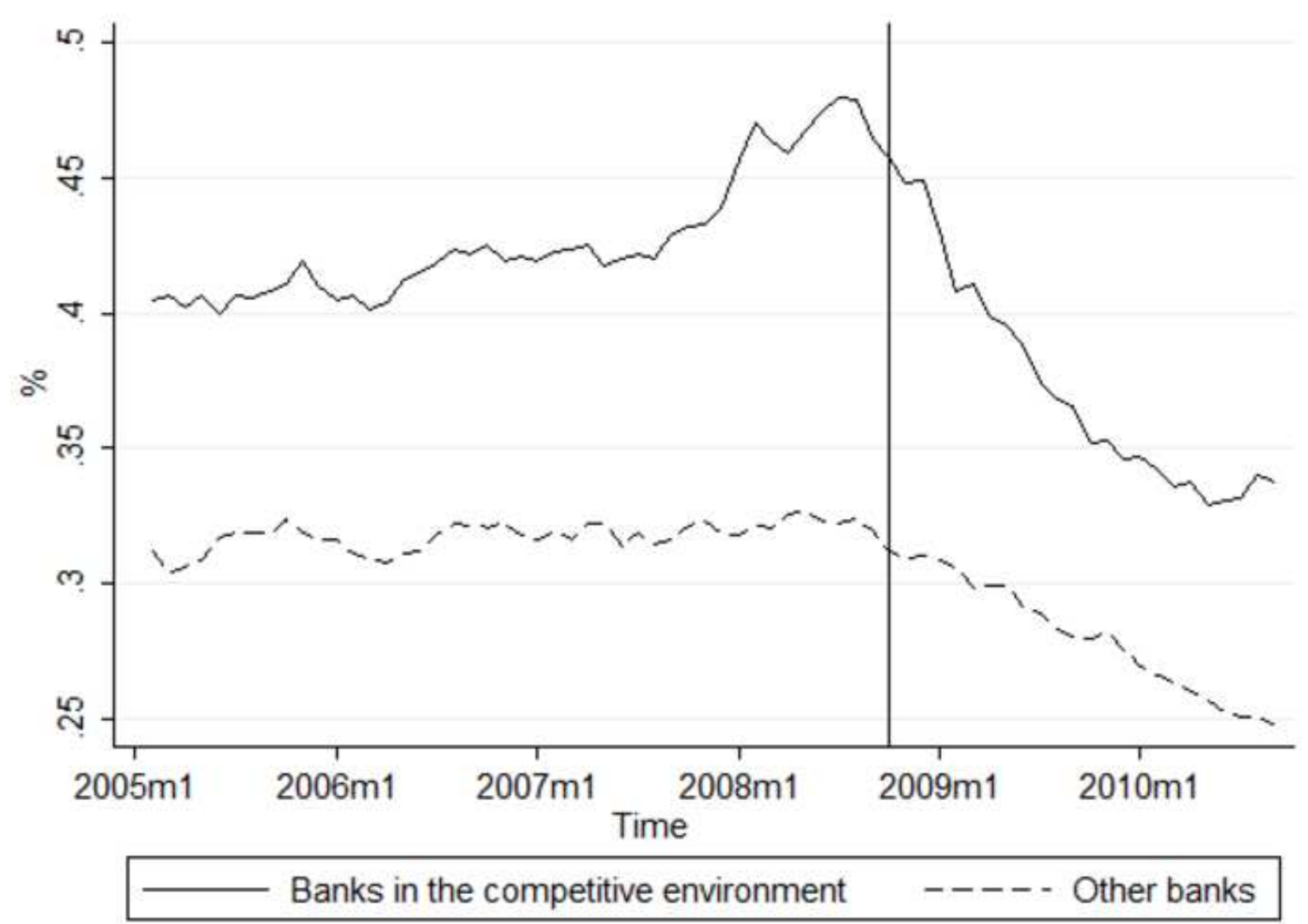

Banks in the competitive environment - - - - Other banks 
Figure B.2

Title:

The development of the average margin of new business loans

Description:

The figure depicts the average trends in the margins of new business loans among the banks that operated in the most competitive environments before the crisis and among the other banks. 


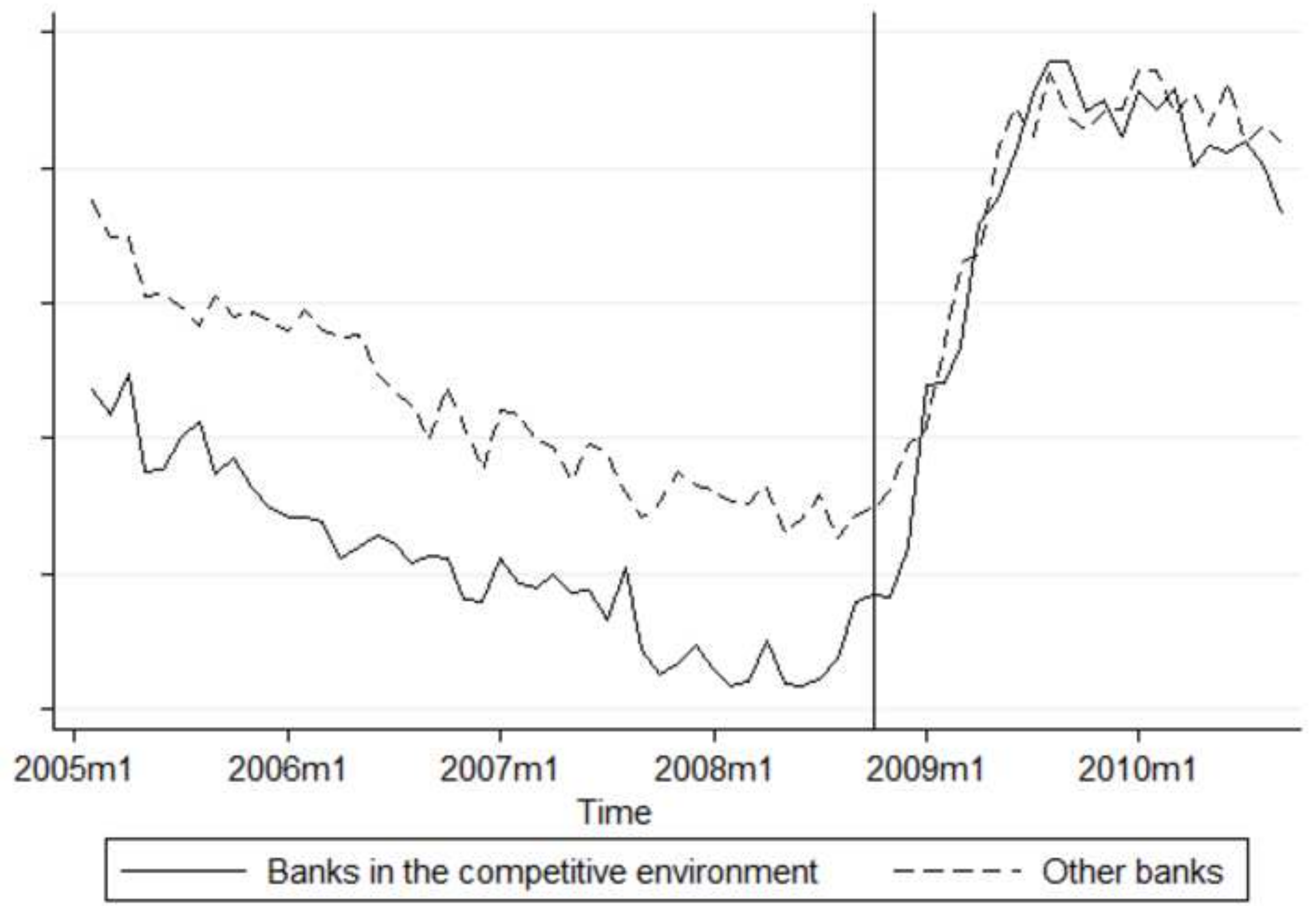


Table 1

Descriptive statistics before and during the crisis

\begin{tabular}{|c|c|c|c|c|c|c|}
\hline \multirow[b]{3}{*}{ Dependent variables } & \multicolumn{2}{|c|}{ mean } & \multicolumn{2}{|c|}{ standard deviation } & \multicolumn{2}{|c|}{ number of observations } \\
\hline & before crisis & crisis & before crisis & crisis & before crisis & crisis \\
\hline & & & & & & \\
\hline New business loans/total assets (\%) & 0.34 & 0.28 & 0.34 & 0.30 & 11032 & 4728 \\
\hline Margin of new business loans (\%-points) & 1.29 & 1.58 & 0.49 & 0.52 & 10140 & 4322 \\
\hline \multicolumn{7}{|l|}{ Competition variables } \\
\hline Lerner index & 0.31 & 0.18 & 0.10 & 0.13 & 959 & 392 \\
\hline HHI & 0.59 & 0.61 & 0.29 & 0.30 & 980 & 392 \\
\hline \multicolumn{7}{|l|}{ Bank characteristics } \\
\hline Short-term, market-based funding/assets (\%) & 5.02 & 5.82 & 5.02 & 8.09 & 10938 & 4707 \\
\hline Capital adequacy ratio $(\%)$ & 21.27 & 23.04 & 5.88 & 6.02 & 11229 & 4728 \\
\hline Liquid assets/total assets (\%) & 3.01 & 2.30 & 2.90 & 2.47 & 11229 & 4728 \\
\hline The log of the total assets & 18.18 & 18.41 & 1.10 & 1.10 & 11229 & 4728 \\
\hline Nonperforming loans/total assets (\%) & 0.66 & 0.59 & 0.55 & 0.53 & 11229 & 4728 \\
\hline OBS commitments/total assets (\%) & 4.80 & 4.87 & 1.86 & 1.90 & 11229 & 4728 \\
\hline \multicolumn{7}{|l|}{ Local economic conditions } \\
\hline Unemployment rate $(\%)$ & 10.15 & 10.42 & 3.80 & 3.19 & 985 & 384 \\
\hline Personal income (thousand euros) & 22.38 & 23.62 & 2.97 & 2.75 & 985 & 394 \\
\hline The change in number of corporations (\%) & 2.78 & 1.28 & 2.41 & 2.52 & 980 & 392 \\
\hline The change in sales of establishments (\%) & 6.44 & -3.55 & 9.43 & 13.02 & 985 & 394 \\
\hline
\end{tabular}


Table 2

Volumes and margins of new business loans before and after the onset of the financial crisis (bivariate tests)

$$
\text { Competitive }
$$

Panel A: New loans/ Total assets in the previous month, Competition measure: Lerner index

Before October 2008

0.411

0.297

$-0.113 * * *$

After October 2008

0.340

0.253

$-0.087^{*}$

Difference

$-0.071 * * *$

$-0.045 * * *$

$\mathbf{- 0 . 0 2 6 * * *}$

Panel B: New loans / Total assets in the previous month, Competition measure: HHI

\begin{tabular}{|c|c|c|c|}
\hline Before October 2008 & 0.389 & 0.302 & $-0.087 * * *$ \\
\hline After October 2008 & 0.315 & 0.258 & $056^{*}$ \\
\hline Difference & $-0.074 * * *$ & $-0.043 * * *$ & $-0.031 * * *$ \\
\hline
\end{tabular}

Panel C: Margin of new business loans, Competition measure: Lerner index

\begin{tabular}{|c|c|c|c|}
\hline Before October 2008 & 1.089 & 1.324 & $0.235 * * *$ \\
\hline After October 2008 & 1.523 & 1.561 & $0.037 * *$ \\
\hline Difference & $0.434 * * *$ & $0.237 * * *$ & $0.197 * * *$ \\
\hline \multicolumn{4}{|c|}{ Panel D: Margin of new business loans, Competition measure: HHI } \\
\hline Before October 2008 & 1.101 & 1.323 & $0.218 * * *$ \\
\hline After October 2008 & 1.503 & 1.567 & $0.064 * * *$ \\
\hline Difference & $0.398 * * *$ & $0.244 * * *$ & $0.154 * * *$ \\
\hline
\end{tabular}

This table presents mean difference-in-difference (DID) estimates in which, in panels A and B, the dependent variable is the percentage of monthly new business loans divided by total assets in the previous month and in panels C and D the average margin of monthly new business loans. Dependent variables are winsorized at the 99th percentile. The cooperative banks are classified into two groups: competitive, when a cooperative bank's pre-crisis average of the competition measure is at the first quantile; other, otherwise. The classification is based on the Lerner index in panels A and C and on the HHI in panels $\mathrm{B}$ and D. The DID estimates are printed in bold. ***, **, and * denote that the coefficients are statistically significantly different from zero at the $1 \%, 5 \%$, and $10 \%$ levels, respectively 
Table 3

Volumes and margins of new business loans before and after the onset of the financial crisis (multivariate tests)

Panel A. Dependent variable: New loans/ Total assets in the previous month

\begin{tabular}{|c|c|c|c|c|c|}
\hline & (1) & (2) & (3) & (4) & $(5)$ \\
\hline \multirow[t]{2}{*}{ Crisis } & $-0.045 * * *$ & $-0.026 * * *$ & 0.018 & 0.010 & 0.010 \\
\hline & $(0.008)$ & (0.009) & $(0.015)$ & $(0.038)$ & $(0.037)$ \\
\hline \multirow[t]{2}{*}{ Competitive (Lerner) } & $0.113 * * *$ & -0.010 & -0.006 & & \\
\hline & $(0.021)$ & $(0.027)$ & $(0.026)$ & & \\
\hline \multirow[t]{2}{*}{ Crisis x Competitive (Lerner) } & $-0.026^{*}$ & -0.021 & -0.019 & -0.023 & \\
\hline & $(0.015)$ & $(0.017)$ & $(0.016)$ & $(0.017)$ & \\
\hline
\end{tabular}

Crisis x Competitive (HHI)

Short market-based debt dummy

$0.041^{*} \quad 0.046^{*}$

$(0.024) \quad(0.025)$

Crisis x Short market-based debt

$0.025)$

$-0.034 * *$

(0.015)

Bank-specific controls

Local economic variables

Province-specific time trends (before and during crisis)

Time fixed effects

Bank fixed effects

Number of observations

R-squared

$-0.032 *$

(0.017)

Panel B. Dependent variable: Margin of new business loans

yes

\begin{tabular}{|c|c|c|c|c|c|}
\hline & $(1)$ & $(2)$ & $(3)$ & $(4)$ & $(5)$ \\
\hline \multirow[t]{2}{*}{ Crisis } & 0.237 *** & $0.262 * * *$ & $-0.345 * * *$ & $-0.516 * * *$ & $-0.489 * * *$ \\
\hline & $(0.017)$ & $(0.022)$ & $(0.034)$ & $(0.069)$ & $(0.071)$ \\
\hline \multirow[t]{2}{*}{ Competitive (Lerner) } & $-0.235 * * *$ & -0.051 & -0.041 & & \\
\hline & $0.035)$ & $(0.044)$ & $(0.036)$ & & \\
\hline \multirow[t]{2}{*}{ Crisis x Competitive (Lerner) } & $0.197 * * *$ & $0.204 * * *$ & $0.199 * * *$ & $0.189 * * *$ & \\
\hline & $(0.033)$ & $(0.030)$ & $(0.029)$ & $(0.029)$ & \\
\hline \multirow[t]{2}{*}{ Crisis x Competitive (HHI) } & & & & & $0.129 * * *$ \\
\hline & & & & & $(0.037)$ \\
\hline \multirow[t]{4}{*}{ Short market-based debt dummy } & & $0.056^{*}$ & 0.023 & & \\
\hline & & $(0.029)$ & $(0.029)$ & & \\
\hline & & 0.002 & 0.015 & 0.022 & $0.062 *$ \\
\hline & & $(0.030)$ & $(0.031)$ & $(0.031)$ & $(0.034)$ \\
\hline Bank-specific controls & no & yes & yes & yes & yes \\
\hline Local economic variables & no & yes & yes & yes & yes \\
\hline Province-specific time trends (before and during crisis) & no & no & yes & yes & yes \\
\hline Time fixed effects & no & no & no & yes & yes \\
\hline Bank fixed effects & no & no & no & yes & yes \\
\hline Number of observations & 14317 & 13980 & 13980 & 13980 & 13980 \\
\hline R-squared & 0.103 & 0.201 & 0.320 & 0.320 & 0.317 \\
\hline
\end{tabular}

This table presents the result of a regression of loan volumes and margins on crisis, competitive environments, dependence on short-term, market-based funding, and their interactions plus bank and local environment controls. The dependent variable is the percentage of monthly new business loans divided by total assets in the previous month in panel A and the average margin of monthly new business loans in panel B. Dependent variables are winsorized at the 99th percentile. Crisis takes value one after September 2008 and zero otherwise. Competitive takes value one when cooperative bank's pre-crisis average of the competition measure is in the top quantile and zero otherwise. Standard errors, clustered at the bank level, are reported in parentheses. $* * *$, **, and * denote that the coefficients are statistically significantly different from zero at the $1 \%, 5 \%$, and $10 \%$ levels, respectively. 
Table 4

Volumes and margins of new business loans before and after the onset of the financial crisis when competition measures are continuous (cf. Table 3) Panel A. Dependent variable: New loans/ Total assets in the previous month

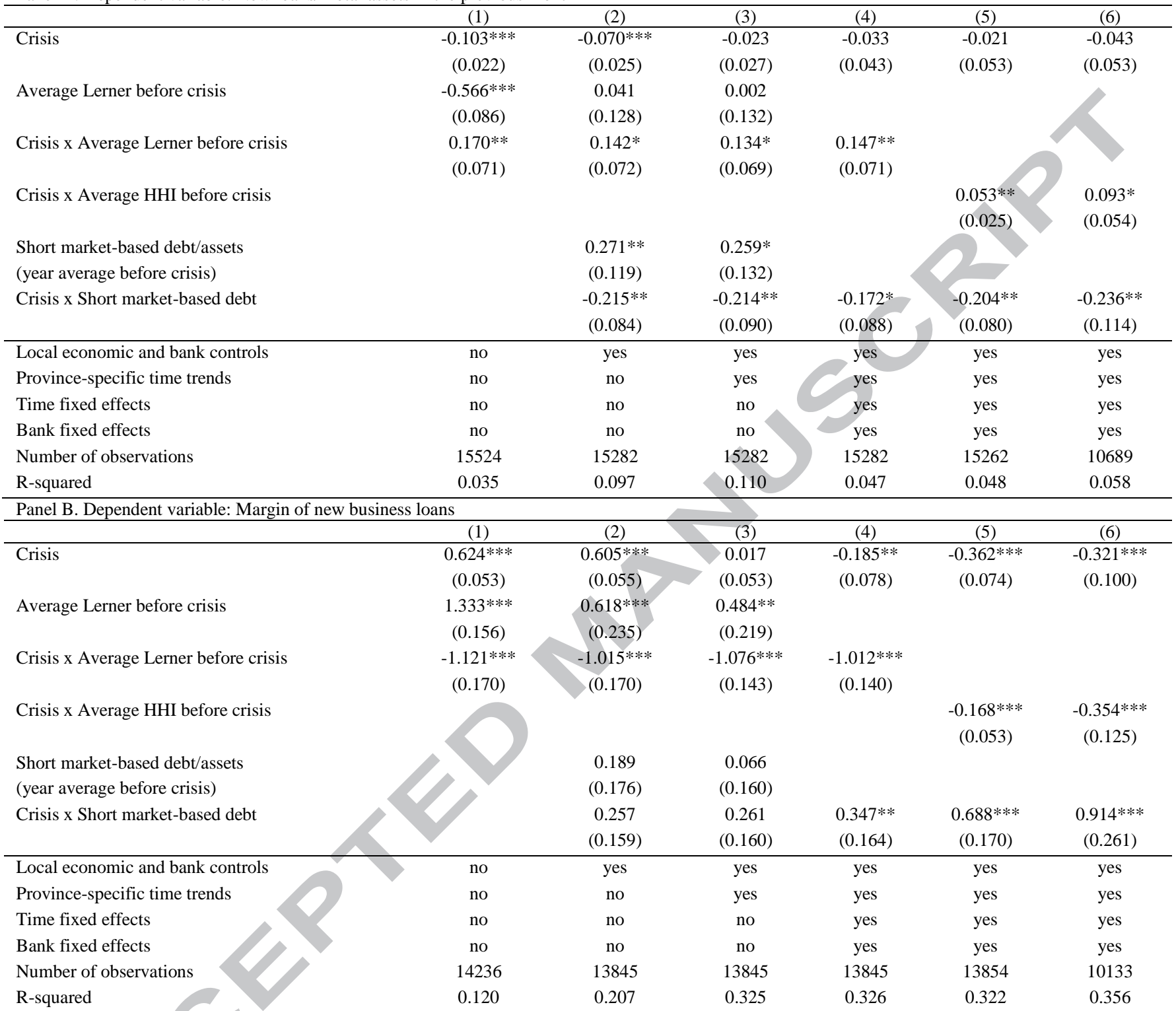

This table presents the regression of loan volumes and margins on crisis, competitive environments, dependence on short-term, market-based funding, and their interactions plus bank and local environment controls. The dependent variable in panel A is the percentage of monthly new business loans divided by total assets in the previous month and in panel B is the average margin of monthly new business loans. Dependent variables are winsorized at the 99th percentile. Crisis takes value one after September 2008 and zero otherwise. The competition measures are calculated as the pre-crisis average. Standard errors, clustered at the bank level, are reported in parentheses. $* * *, * *$, and * denote that the coefficients are statistically significantly different from zero at the $1 \%, 5 \%$, and $10 \%$ levels, respectively. 
Table 5

Comparison of competition measures, prices and dependence on short-term, market-based funding between the banks that operated in the most competitive environments before the crisis and the other banks before and during the crisis

\begin{tabular}{|c|c|c|c|c|c|c|c|}
\hline & \multicolumn{3}{|c|}{ Before October 2008} & \multicolumn{3}{|c|}{ After October 2008} & \multirow[b]{2}{*}{ Diff-in-Diff } \\
\hline Variable & Competitive & Other & Difference & Competitive & Other & Difference & \\
\hline Lerner index & 0.198 & 0.362 & $0.164 * * *$ & 0.085 & 0.236 & $0.150 * * *$ & $-0.013 * * *$ \\
\hline Interest spread & 2.604 & 2.953 & $0.349 * * *$ & 1.627 & 1.870 & $0.243 * * *$ & $-0.106 * * *$ \\
\hline \multicolumn{8}{|l|}{ Interest rates } \\
\hline Interest rate on current account deposits & 0.815 & 0.722 & $-0.094 * * *$ & 0.446 & 0.437 & -0.009 & $-0.085 * * *$ \\
\hline Interest rate on saving deposits & 2.384 & 2.406 & 0.022 & 1.323 & 1.368 & 0.045 & -0.023 \\
\hline Interest rate on new term deposits & 3.438 & 3.343 & $-0.096 * * *$ & 1.952 & 1.968 & 0.016 & $-0.111 * * *$ \\
\hline Average margin on mortgages & 1.067 & 1.265 & $0.199 * * *$ & 1.341 & 1.430 & $0.089 *$ & $-0.109 * * *$ \\
\hline Average margin on consumer loans & 1.527 & 1.771 & $0.244 * * *$ & 1.857 & 1.937 & $0.080^{* * *}$ & $-0.163 * * *$ \\
\hline Short market-based debt/asset & 0.111 & 0.035 & $-0.077 * * *$ & 0.090 & 0.050 & $-0.040 * * *$ & $-0.037 * * *$ \\
\hline
\end{tabular}

This table presents mean difference-in-difference (DID) estimates of competition variables and prices of various loan and deposits. The classification of competitive environment groups is based on the pre-crisis Lerner index. All values are averages for banks in each group. The interest rate spread denotes the difference between the average interest rate on new loans and deposits. Interest rates relate to new monthly deposits and loans. ***, **, and * denote that the coefficients are statistically significantly different from zero at the $1 \%, 5 \%$, and $10 \%$ levels, respectively 
Table 6

An examination of the role of credit risk in heterogeneous changes in volumes and margins of business loans

Panel A. Comparison between average credit ratings of business loans between the banks that operated in the most competitive environments before the crisis and the other banks at the beginning and at the end of the crisis period

\begin{tabular}{|c|c|c|c|c|c|c|c|}
\hline & \multicolumn{3}{|c|}{ September 2008} & \multicolumn{3}{|c|}{ September 2010} & \\
\hline Variable & Competitive & Other & Difference & Competitive & Other & Difference & Diff-in-Diff \\
\hline Average risk rating of business loans & 6.657 & 6.771 & 0.113 & 6.823 & 7.106 & $0.279^{* * * *}$ & -0.166 \\
\hline Number of observations & 39 & 158 & & 39 & 158 & & 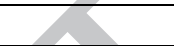 \\
\hline \multicolumn{8}{|c|}{ Panel B. The effect of the pre-crisis competitive environment on loan margin based on loan-specific data. } \\
\hline & \multicolumn{4}{|c|}{ Margin of stock of business loans in September 2008} & \multicolumn{3}{|c|}{ Margin of new business loans during the crisis } \\
\hline & $(1)$ & & $(2)$ & & (3) & & $(4)$ \\
\hline Competitive (Lerner) & $\begin{array}{c}-0.122 * * * \\
(0.005)\end{array}$ & & & & $\begin{array}{l}0.062 * * * \\
(0.006)\end{array}$ & & \\
\hline Competitive (HHI) & & & $\begin{array}{c}-0.077 * * * \\
(0.005)\end{array}$ & & & & $\begin{array}{c}0.056 * * * \\
(0.006)\end{array}$ \\
\hline Risk rating & $\begin{array}{c}0.088 * * * \\
(0.001)\end{array}$ & & $\begin{array}{c}0.088^{*} * * \\
(0.001)\end{array}$ & & $\begin{array}{l}0.081 * * * * \\
(0.002)\end{array}$ & & $\begin{array}{c}0.081 * * * \\
(0.002)\end{array}$ \\
\hline Ln(loan amount) & $\begin{array}{c}-0.154 * * * \\
(0.002)\end{array}$ & & $\begin{array}{c}-0.156^{* * * *} \\
(0.002)\end{array}$ & & $\begin{array}{l}0.125^{* * * *} \\
(0.003)\end{array}$ & & $\begin{array}{c}-0.124 * * * \\
(0.003)\end{array}$ \\
\hline Time fixed effects & no & & no & & yes & & yes \\
\hline Number of observations & 49110 & & 49110 & & 30099 & & 30099 \\
\hline R-squared & 0.225 & & 0.219 & & 0.213 & & 0.213 \\
\hline
\end{tabular}

This table presents mean difference-in-difference (DID) estimates of average credit ratings for different pre-crisis competition environments (panel A) and loan-level regressions of loan margins for competitive environments, internal credit ratings and loan sizes (panel B). Competitive takes value one when cooperative bank's pre-crisis average of the competition measure is in the top quantile and zero otherwise. Standard errors are reported in parentheses in panel B. ***, **, and * denote that coefficients differ significantly from zero at the $1 \%, 5 \%$, and $10 \%$ levels, respectively. 